\title{
LEVEL II SCOUR ANALYSIS FOR BRIDGE 39 (ANDOVT00110039) on STATE ROUTE 11, crossing the MIDDLE BRANCH WILLIAMS RIVER, ANDOVER, VERMONT
}

U.S. Geological Survey

Open-File Report 97-373

Prepared in cooperation with

VERMONT AGENCY OF TRANSPORTATION

and

FEDERAL HIGHWAY ADMINISTRATION 


\section{LEVEL II SCOUR ANALYSIS FOR BRIDGE 39 (ANDOVT00110039) on STATE ROUTE 11, crossing the MIDDLE BRANCH WILLIAMS RIVER, ANDOVER, VERMONT \\ By Ronda L. Burns and Emily C. Wild}

U.S. Geological Survey Open-File Report 97-373

Prepared in cooperation with

VERMONT AGENCY OF TRANSPORTATION

and

FEDERAL HIGHWAY ADMINISTRATION

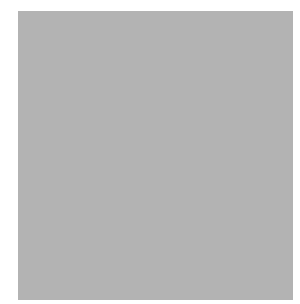




\title{
U.S. DEPARTMENT OF THE INTERIOR BRUCE BABBITT, Secretary
}

\author{
U.S. GEOLOGICAL SURVEY \\ Gordon P. Eaton, Director
}

For additional information write to:

District Chief

U.S. Geological Survey 361 Commerce Way

Pembroke, NH 03275-3718
Copies of this report may be purchased from:

U.S. Geological Survey

Branch of Information Services

Open-File Reports Unit

Box 25286

Denver, CO 80225-0286 


\section{CONTENTS}

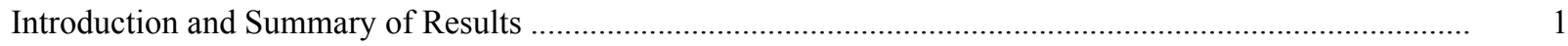

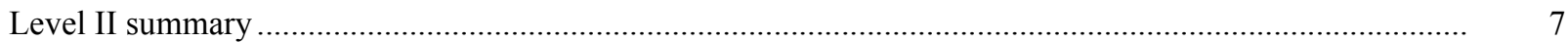

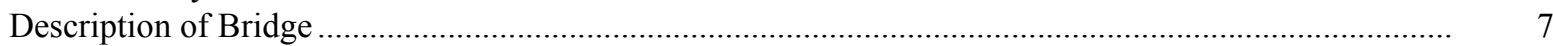

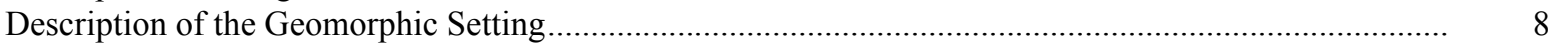

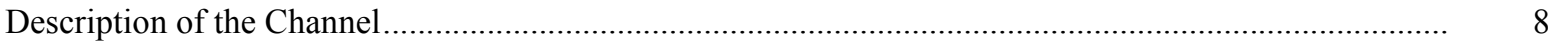

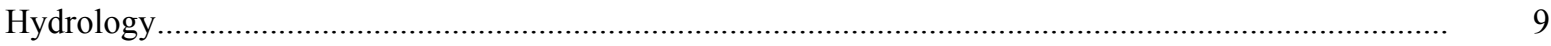

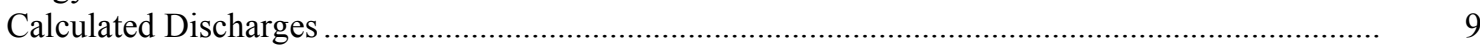

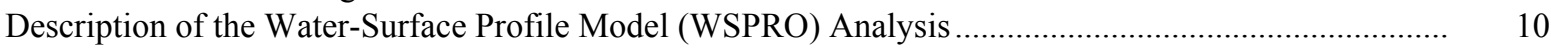

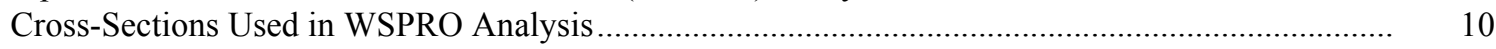

Data and Assumptions Used in WSPRO Model ...................................................................... 11

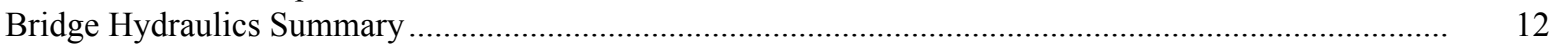

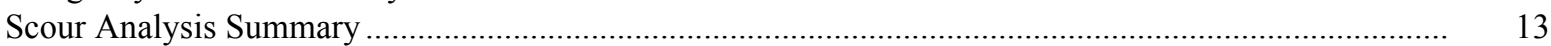

Special Conditions or Assumptions Made in Scour Analysis ...................................................... 13

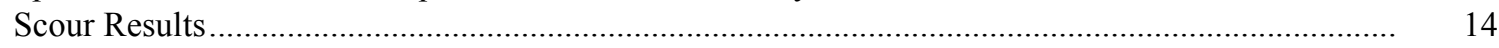

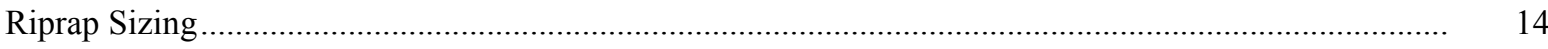

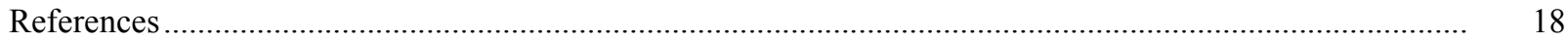

Appendixes:

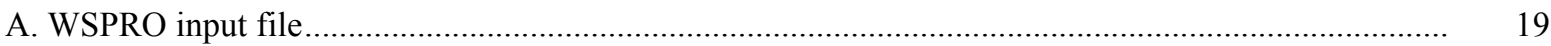

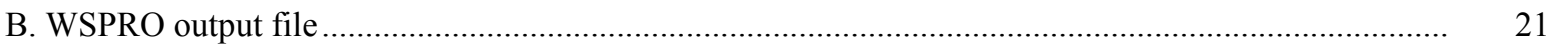

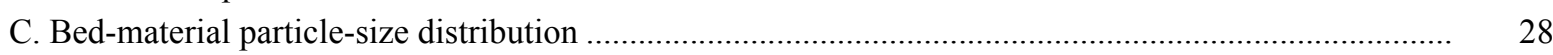

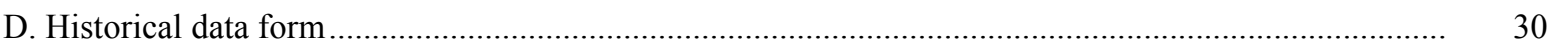

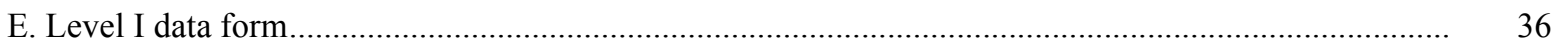

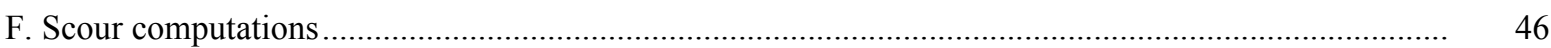

\section{FIGURES}

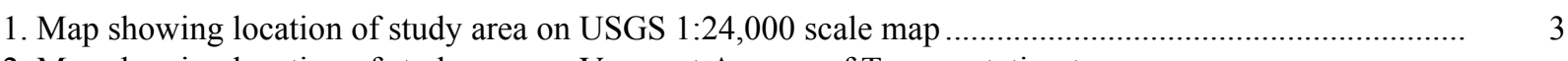

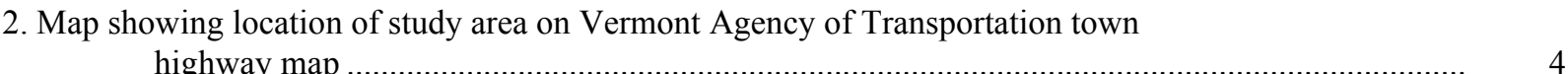

3. Structure ANDOVT00110039 viewed from upstream (September 9, 1996) ........................................... 5

4. Downstream channel viewed from structure ANDOVT00110039 (September 9, 1996)......................... 5

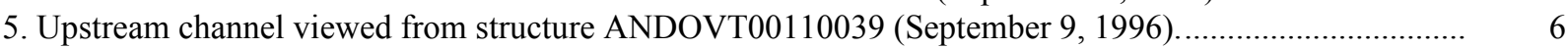

6. Structure ANDOVT00110039 viewed from downstream (September 9, 1996). ................................... 6

7. Water-surface profiles for the 100- and 500-year discharges at structure

ANDOVT00110039 on State Route 11, crossing the Middle Branch Williams River,

Andover, Vermont.

8. Scour elevations for the 100- and 500-year discharges at structure

ANDOVT00110039 on State Route 11, crossing the Middle Branch Williams River,

Andover, Vermont.

\section{TABLES}

1. Remaining footing/pile depth at abutments for the 100-year discharge at structure

ANDOVT00110039 on State Route 11, crossing the Middle Branch Williams River,

Andover, Vermont

2. Remaining footing/pile depth at abutments for the 500-year discharge at structure

ANDOVT00110039 on State Route 11, crossing the Middle Branch Williams River,

Andover, Vermont 


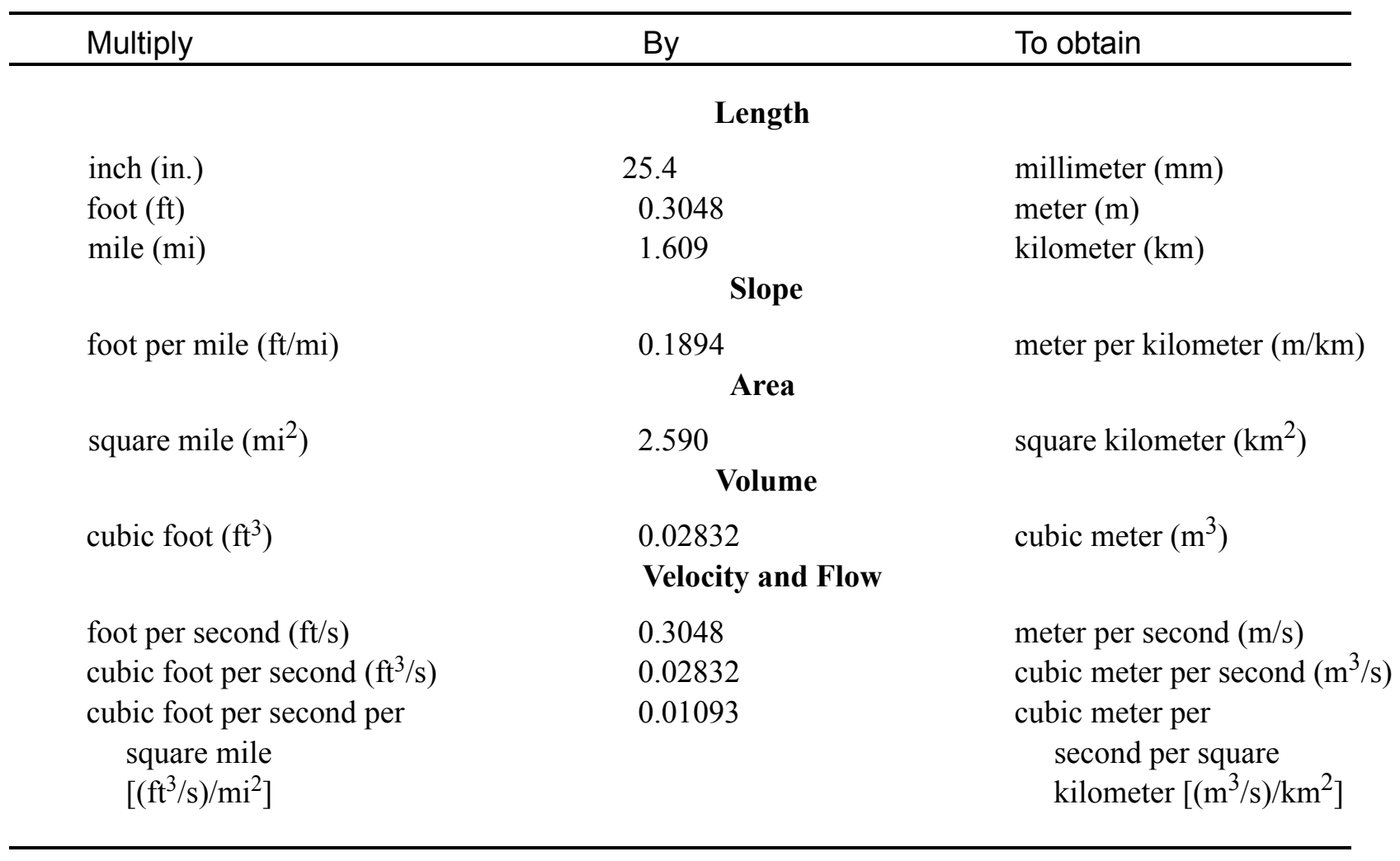

\section{OTHER ABBREVIATIONS}

$\begin{array}{lrlr}\mathrm{BF} & \text { bank full } & \text { LWW } & \text { left wingwall } \\ \mathrm{cfs} & \text { cubic feet per second } & \text { MC } & \text { main channel } \\ \mathrm{D}_{50} & \text { median diameter of bed material } & \text { RAB } & \text { right abutment } \\ \mathrm{DS} & \text { downstream } & \text { RABUT } & \text { face of right abutment } \\ \mathrm{elev} & \text { elevation } & \text { RB } & \text { right bank } \\ \mathrm{f} / \mathrm{p} & \text { flood plain } & \text { ROB } & \text { right overbank } \\ \mathrm{ft}^{2} & \text { square feet } & \text { RWW } & \text { right wingwall } \\ \mathrm{ft} / \mathrm{ft} & \text { feet per foot } & \text { TH } & \text { town highway } \\ \mathrm{JCT} & \text { junction } & \text { UB } & \text { under bridge } \\ \mathrm{LAB} & \text { left abutment } & \text { US } & \text { upstream } \\ \mathrm{LABUT} & \text { face of left abutment } & \text { USGS } & \text { United States Geological Survey } \\ \mathrm{LB} & \text { left bank } & \text { VTAOT Vermont Agency of Transportation } \\ \mathrm{LOB} & \text { left overbank } & \text { WSPRO } & \text { water-surface profile model }\end{array}$

In this report, the words "right" and "left" refer to directions that would be reported by an observer facing downstream. Sea level: In this report, "sea level" refers to the National Geodetic Vertical Datum of 1929-- a geodetic datum derived from a general adjustment of the first-order level nets of the United States and Canada, formerly called Sea Level Datum of 1929.

In the appendices, the above abbreviations may be combined. For example, USLB would represent upstream left bank. 


\title{
LEVEL II SCOUR ANALYSIS FOR BRIDGE 39 (ANDOVT00110039) ON STATE ROUTE 11, CROSSING THE MIDDLE BRANCH WILLIAMS RIVER, ANDOVER, VERMONT
}

\author{
By Ronda L. Burns and Emily C. Wild
}

\section{INTRODUCTION AND SUMMARY OF RESULTS}

This report provides the results of a detailed Level II analysis of scour potential at structure ANDOVT00110039 on State Route 11 crossing the Middle Branch Williams River, Andover, Vermont (figures 1-8). A Level II study is a basic engineering analysis of the site, including a quantitative analysis of stream stability and scour (U.S. Department of Transportation, 1993). Results of a Level I scour investigation also are included in Appendix E of this report. A Level I investigation provides a qualitative geomorphic characterization of the study site. Information on the bridge, gleaned from Vermont Agency of Transportation (VTAOT) files, was compiled prior to conducting Level I and Level II analyses and is found in Appendix D.

The site is in the Green Mountain section of the New England physiographic province in southern Vermont. The $5.75-\mathrm{mi}^{2}$ drainage area is in a predominantly rural and forested basin. In the vicinity of the study site, the surface cover is forest on the upstream left bank and downstream right bank. The surface cover on the upstream right and downstream left banks is brush.

In the study area, the Middle Branch Williams River has an incised, sinuous channel with a slope of approximately $0.01 \mathrm{ft} / \mathrm{ft}$, an average channel top width of $58 \mathrm{ft}$ and an average bank height of $8 \mathrm{ft}$. The channel bed material ranges from sand to boulder with a median grain size $\left(\mathrm{D}_{50}\right)$ of $96.8 \mathrm{~mm}(0.317 \mathrm{ft})$. The geomorphic assessment at the time of the Level I and Level II site visit on September 9, 1996, indicated that the reach was laterally unstable.

The State Route 11 crossing of the Middle Branch Williams River is a 43-ft-long, two-lane bridge consisting of one 41 -foot concrete-beam span and two additional steel beams on the upstream face (Vermont Agency of Transportation, written communication, March 29, 1995). The bridge is supported by vertical, concrete abutments with wingwalls. The channel is skewed approximately 45 degrees to the opening while the opening-skew-to-roadway is 45 degrees. 
The only scour protection measures at the site was type- 2 stone fill (less than 36 inches diameter) at the upstream end of the upstream right wingwall and type-3 stone fill (less than 48 inches diameter) along the entire base length of the upstream left wingwall. Additional details describing conditions at the site are included in the Level II Summary and Appendices D and E.

Scour depths and recommended rock rip-rap sizes were computed using the general guidelines described in Hydraulic Engineering Circular 18 (Richardson and others, 1995). Total scour at a highway crossing is comprised of three components: 1) long-term streambed degradation; 2) contraction scour (due to accelerated flow caused by a reduction in flow area at a bridge) and; 3 ) local scour (caused by accelerated flow around piers and abutments). Total scour is the sum of the three components. Equations are available to compute depths for contraction and local scour and a summary of the results of these computations follows.

Contraction scour for all modelled flows ranged from 0.0 to $0.8 \mathrm{ft}$. The worst-case contraction scour occurred at the 500-year discharge. Abutment scour ranged from 8.9 to $11.2 \mathrm{ft}$. The worst-case abutment scour occurred at the incipient-overtopping discharge. Additional information on scour depths and depths to armoring are included in the section titled "Scour Results". Scoured-streambed elevations, based on the calculated scour depths, are presented in tables 1 and 2. A cross-section of the scour computed at the bridge is presented in figure 8 . Scour depths were calculated assuming an infinite depth of erosive material and a homogeneous particle-size distribution.

It is generally accepted that the Froehlich equation (abutment scour) gives "excessively conservative estimates of scour depths" (Richardson and others, 1995, p. 47). Usually, computed scour depths are evaluated in combination with other information including (but not limited to) historical performance during flood events, the geomorphic stability assessment, existing scour protection measures, and the results of the hydraulic analyses. Therefore, scour depths adopted by VTAOT may differ from the computed values documented herein. 


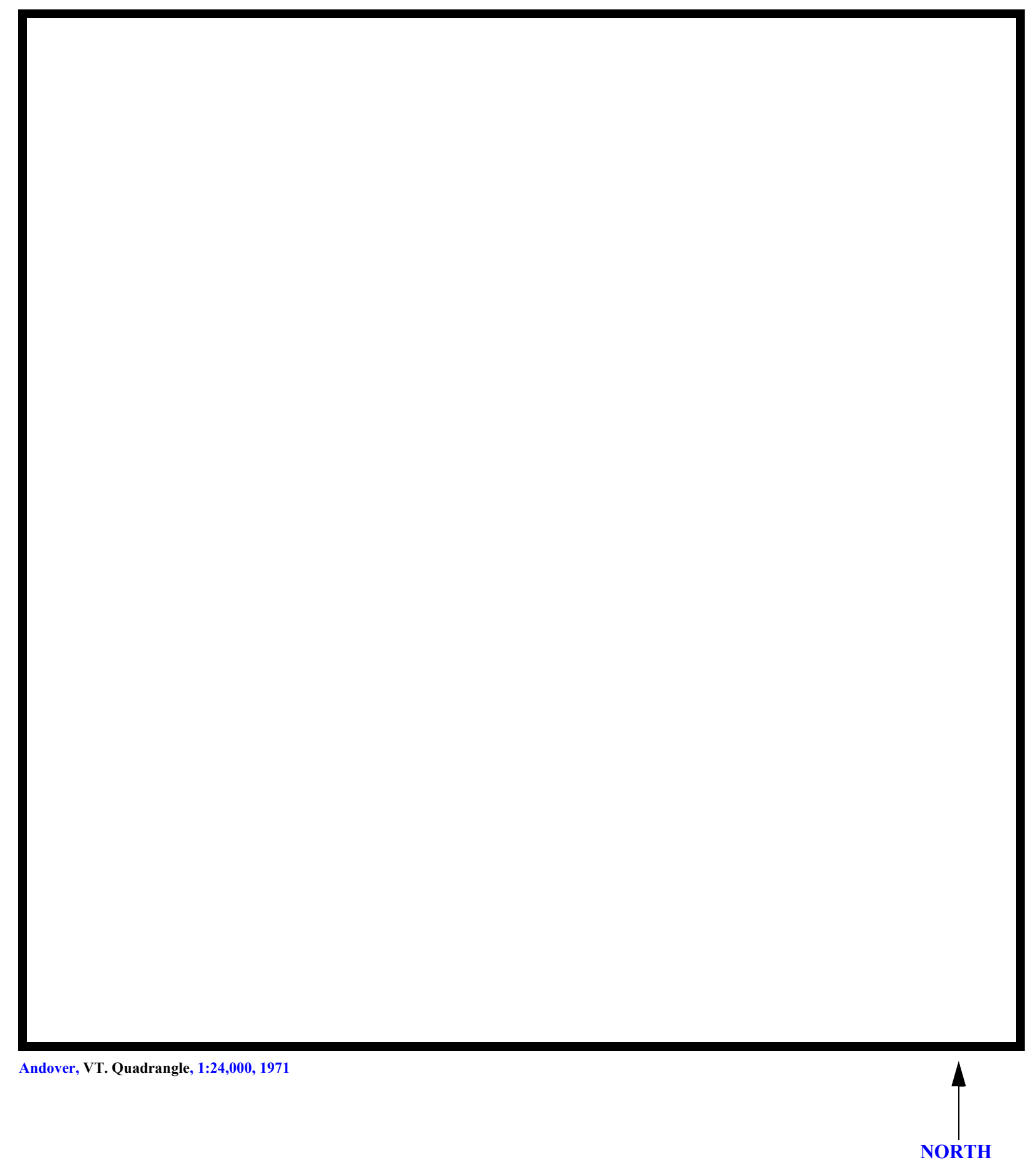

Figure 1. Location of study area on USGS 1:24,000 scale map. 
Figure 2. Location of study area on Vermont Agency of Transportation town highway map. 

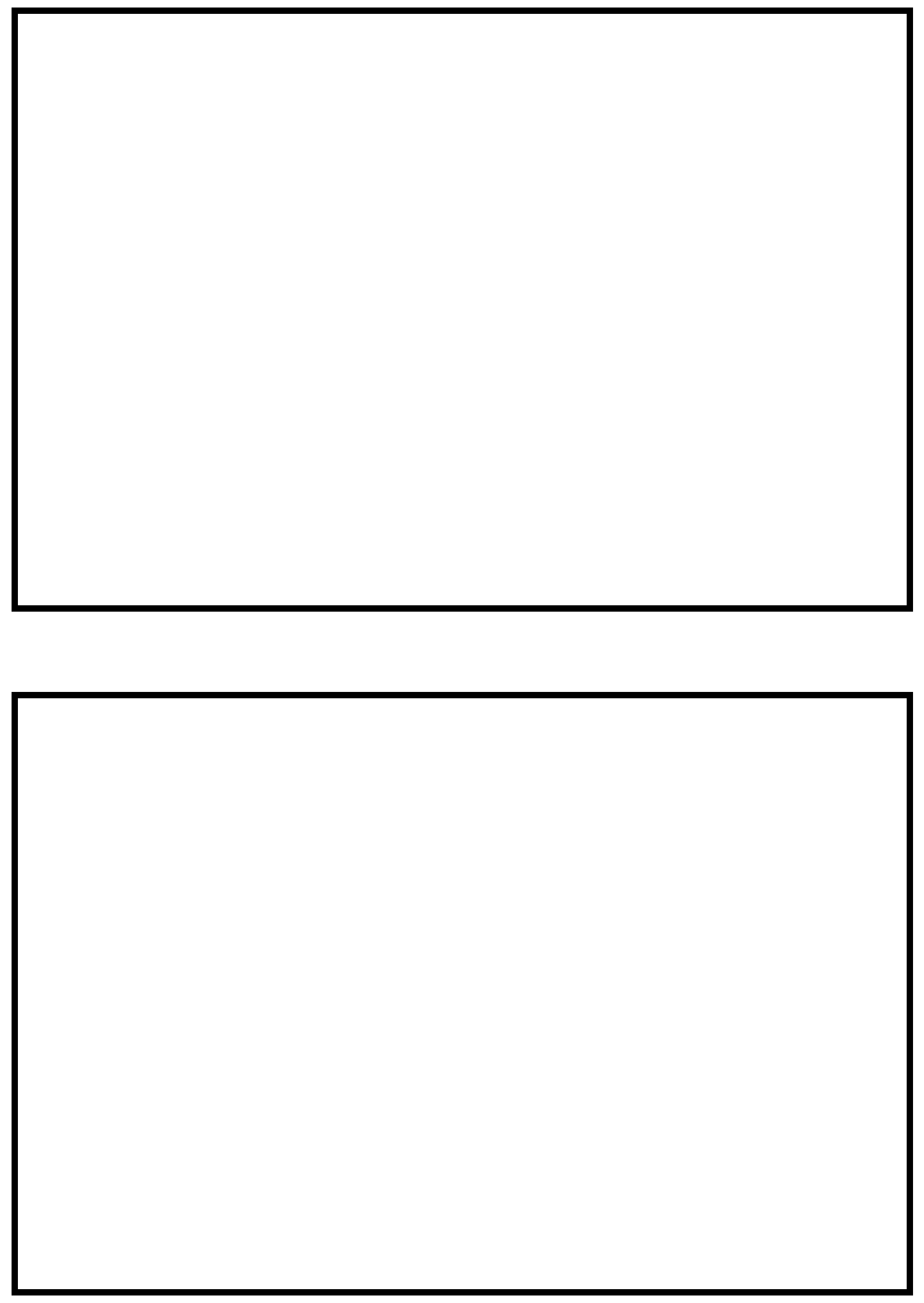

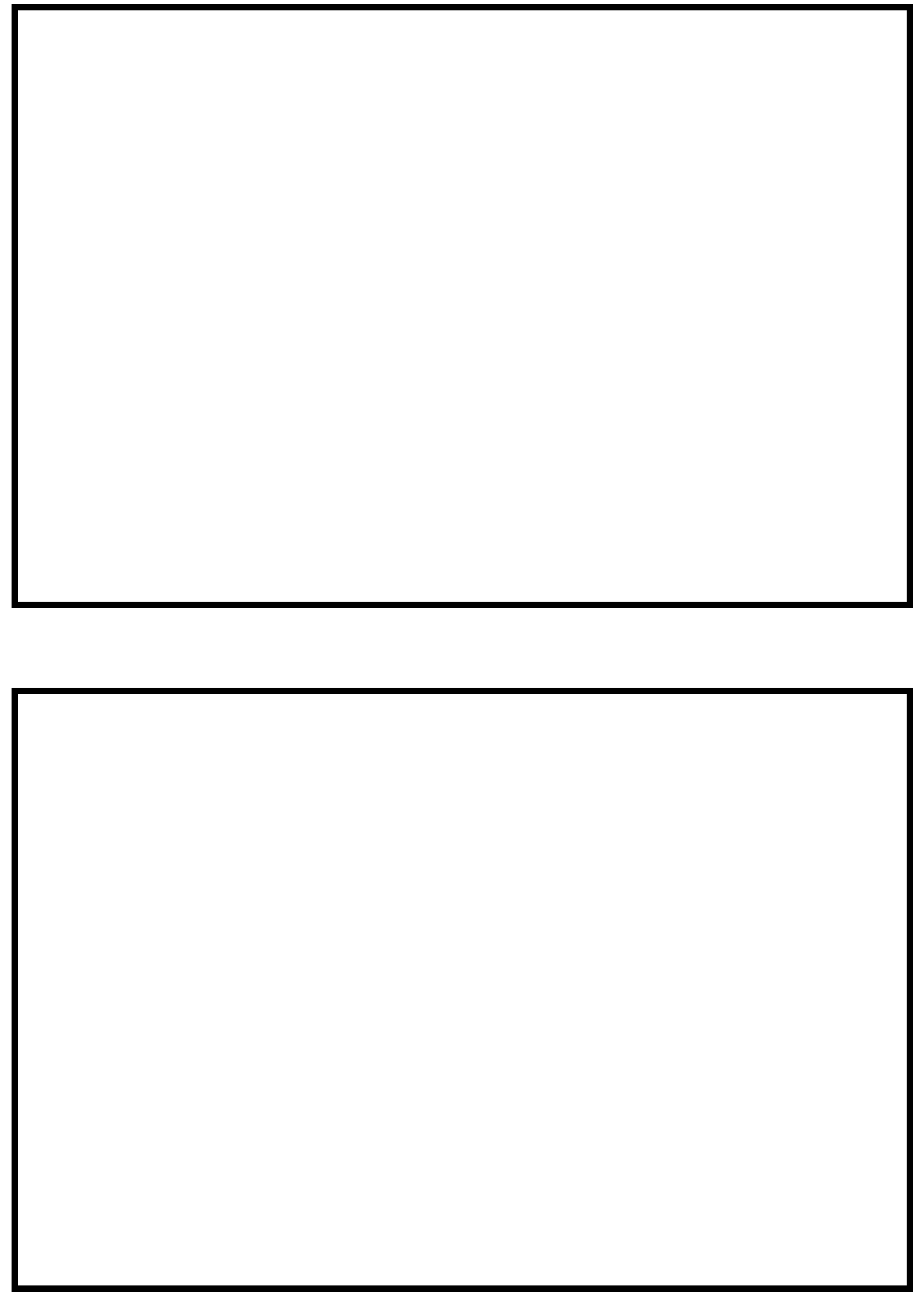


\section{LEVEL II SUMMARY}

\begin{tabular}{llllll} 
& Structure Number & ANDOVT00110039 & & \multicolumn{3}{c}{ Middle Branch Williams River } \\
Stream & & & & \\
County & Windham & Road & VT11 & District & 2
\end{tabular}

\section{Description of Bridge}

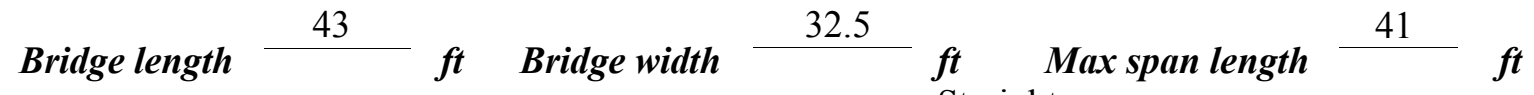
Alignment of bridge to road (on curve or straight)

Abutment type Vertical, concrete

Stone fill on abutment?
Straight

$$
\text { Sloping }
$$

\section{Embankment type}

No

\section{Dato af incnortion}

type-3 along the base of the upstream left wingwall.

Abutments and wingwalls are concrete.

$\cdots+\ldots$

\section{$\mathrm{Y}$}

Is bridge skewed to flood flow according to $\mathrm{Y} \quad$ 'survey? Angle

45

Is bridge skewed to flood flow according to Y ' survey? Angle

The channel bends mildly in the upstream reach and in the downstream reach. . ..........,

Debris accumulation on bridge at time of Level I or Level II site visit:

Date of insnortion 09/09/97

Level I

$09 / 09 / 97$

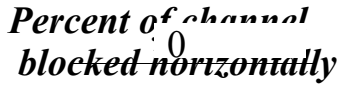

0
Percent of allonel
blocked verticatty

0

Level II

Moderate. In the upstream reach there are some very large trees down in the middle of the channel.

Potential for debris

None (09/09/97).

Doscriho anv fonturos noar ar at tho hridoo that mav, affort flow, (includo ahsomation dato) 


\section{Description of the Geomorphic Setting}

General topography The channel is located within a narrow valley with steep valley walls on both sides.

Geomorphic conditions at bridge site: downstream (DS), upstream (US)

Date of inspection $\quad 09 / 09 / 97$

DS left: $\quad$ Steep valley wall

DS right: $\quad$ Steep valley wall

US left: $\quad$ Steep valley wall

US right: $\quad$ Steep valley wall

\section{Description of the Channel}

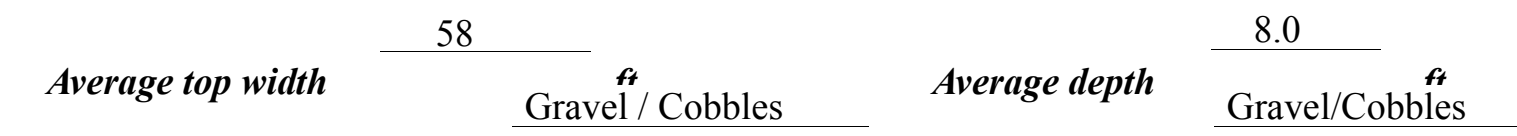

Predominant bed material

Bank material Sinuous and unstable

with semi-alluvial channel boundaries and no flood plain.

$09 / 09 / 97$

Vegetative co 1 Small trees and brush

DS left: $\quad$ Trees

DS right: Trees

US left: $\quad$ Short grass and brush.

US right: $\quad \underline{\mathrm{N}}$

Do banks appear stable? The channel bends both upstream and downstream where it widens

dand there are wide point bars. There is moderate fluvial erosion on the downstream right bank and cut banks on the upstream left and downstream right banks.

None (09/09/97).

Describe any obstructions in channel and date of observation. 


\section{Hydrology}

Drainage area $\quad \frac{5.75}{m^{2}}{ }^{2}$

Percentage of drainage area in physiographic provinces: (approximate)

Physiographic province/section

New England/Green Mountain
Percent of drainage area 100

Is drainage area considered rural or urban? Rural Describe any significant urbanization:

Is there a USGS gage on the stream of interest?

No

USGS gage description

USGS gage number

Gage drainage area $\mathrm{mi}^{2}$

No

Is there a lake/p

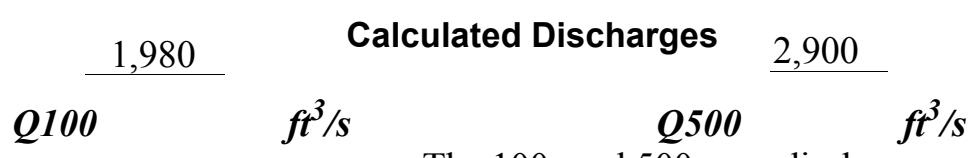

The 100- and 500-year discharges are based on a

drainage area relationship [(5.8/14.8 8 exp 0.68] with the drainage area above the Andover Branch confluence with the Middle Branch Williams River in Chester. This drainage area is 14.8 square miles and has flood frequency estimates available in the Flood Insurance Study for the town of Chester (Federal Emergency Management Agency, February 1982). These values are within a range defined by several empirical flood frequency curves (Benson, 1962; Johnson and Tasker, 1974; FHWA, 1983; Potter, 1957a\&b; Talbot, 1887). 


\section{Description of the Water-Surface Profile Model (WSPRO) Analysis}

Datum for WSPRO analysis (USGS survey, sea level, VTAOT plans)

USGS survey

Datum tie between USGS survey and VTAOT plans

Subtract $50.9 \mathrm{ft}$. from the USGS

survey to obtain VTAOT plans' datum.

Description of reference marks used to determine USGS datum. $\quad$ RM11 is a chiseled X on

top of the downstream end of the right abutment (elev. $446.50 \mathrm{ft}$, arbitrary survey datum).

RM12 is a chiseled X on top of the upstream end of the left abutment (elev. $446.22 \mathrm{ft}$, arbitrary

survey datum).

Cross-Sections Used in WSPRO Analysis

\begin{tabular}{|c|c|c|c|}
\hline${ }^{1}$ Cross-section & $\begin{array}{c}\text { Section } \\
\text { Reference } \\
\text { Distance } \\
\text { (SRD) in feet }\end{array}$ & $\begin{array}{c}{ }^{2} \text { Cross-section } \\
\text { development }\end{array}$ & Comments \\
\hline EXITX & -32 & 1 & Exit section \\
\hline FULLV & 0 & 2 & $\begin{array}{l}\text { Downstream Full-valley } \\
\text { section (Templated from } \\
\text { EXITX) }\end{array}$ \\
\hline BRIDG & 0 & 1 & Bridge section \\
\hline RDWAY & 21 & 1 & Road Grade section \\
\hline APPRO & 67 & 2 & $\begin{array}{l}\text { Modelled Approach sec- } \\
\text { tion (Templated from } \\
\text { APTEM) }\end{array}$ \\
\hline APTEM & 113 & 1 & $\begin{array}{l}\text { Approach section as sur- } \\
\text { veyed (Used as a tem- } \\
\text { plate) }\end{array}$ \\
\hline
\end{tabular}

${ }^{1}$ For location of cross-sections see plan-view sketch included with Level I field form, Appendix E.

For more detail on how cross-sections were developed see WSPRO input file. 


\section{Data and Assumptions Used in WSPRO Model}

Hydraulic analyses of the reach were done by use of the Federal Highway Administration's WSPRO step-backwater computer program (Shearman and others, 1986, and Shearman, 1990). The analyses reported herein reflect conditions existing at the site at the time of the study. Furthermore, in the development of the model it was necessary to assume no accumulation of debris or ice at the site. Results of the hydraulic model are presented in the Bridge Hydraulic Summary, Appendix B, and figure 7.

Channel roughness factors (Manning's “ $n$ ”) used in the hydraulic model were estimated using field inspections at each cross section following the general guidelines described by Arcement and Schneider (1989). Final adjustments to the values were made during the modelling of the reach. Channel " $\mathrm{n}$ " values for the reach ranged from 0.045 to 0.060 , and overbank " $\mathrm{n}$ " values ranged from 0.035 to 0.100 .

Normal depth at the exit section (EXITX) was assumed as the starting water surface. This depth was computed by use of the slope-conveyance method outlined in the user's manual for WSPRO (Shearman, 1990). The slope used was $0.0143 \mathrm{ft} / \mathrm{ft}$ which was calculated from surveyed points downstream.

The surveyed approach section (APTEM) was moved along the approach channel slope $(0.0079 \mathrm{ft} / \mathrm{ft})$ to establish the modelled approach section (APPRO), one bridge length upstream of the upstream face as recommended by Shearman and others (1986). This approach also provides a consistent method for determining scour variables. 


\section{Bridge Hydraulics Summary}

$\begin{array}{lll}\text { Average bridge embankment elevation } & 446.5 & f t \\ \text { Average low steel elevation } & 442.9 & \boldsymbol{f t}\end{array}$

100-year discharge $1,980 \quad \mathrm{ft}^{3} / \mathrm{s}$

Water-surface elevation in bridge opening $\quad 443.1 \quad f t$

Road overtopping? ___ N Discharge over road ___ - $\mathrm{ft}^{3} / \mathrm{s}$

\begin{tabular}{llll} 
Area of flow in bridge opening & $218 \quad \boldsymbol{f t}^{2}$ \\
\cline { 2 - 3 } Average velocity in bridge opening & 9.1 & $\boldsymbol{f t} / \mathrm{s}$
\end{tabular}

Maximum WSPRO tube velocity at bridge $\quad 10.8 \mathrm{ft} / \mathrm{s}$

Water-surface elevation at Approach section with bridge

Water-surface elevation at Approach section without bridge

445.3

Amount of backwater caused by bridge

4.8 it

500-year discharge $\quad 2,900 \quad \mathrm{ft}^{3} / \mathrm{s}$

Water-surface elevation in bridge opening

$443.1 \mathrm{ft}$

Road overtopping? ___ Y Discharge over road __ $462 \quad \mathrm{ft}^{3} / \mathrm{s}$

Area of flow in bridge opening $\quad 218 \quad \mathrm{ft}^{2}$

Average velocity in bridge opening $11.2 \mathrm{ft} / \mathrm{s}$

Maximum WSPRO tube velocity at bridge 13.2 , 's

Water-surface elevation at Approach section with bridge 447.6

Water-surface elevation at Approach section without bridge $\quad 441.7$

Amount of backwater caused by bridge $\quad 5.9$.t

Incipient overtopping discharge $\quad 2,250 \quad \mathrm{ft}^{3} / \mathrm{s}$

Water-surface elevation in bridge opening $443.1 \quad$ it

Area of flow in bridge opening $218 \quad \mathrm{ft}^{2}$

Average velocity in bridge opening $\quad 10.3 \mathrm{ft} / \mathrm{s}$

Maximum WSPRO tube velocity at bridge $\quad 12.2 \quad \mathrm{ft} / \mathrm{s}$

Water-surface elevation at Approach section with bridge

Water-surface elevation at Approach section without bridge

Amount of backwater caused by bridge $\quad 5.7$ it

446.6

440.9 


\section{Scour Analysis Summary}

\section{Special Conditions or Assumptions Made in Scour Analysis}

Scour depths were computed using the general guidelines described in Hydraulic Engineering Circular 18 (Richardson and others, 1995). Scour depths were calculated assuming an infinite depth of erosive material and a homogeneous particle-size distribution. The results of the scour analysis are presented in tables 1 and 2 and a graph of the scour depths is presented in figure 8 .

The 100-year, 500-year and incipient road-overflow discharges resulted in unsubmerged orifice flow. Contraction scour at bridges with orifice flow is best estimated by use of the Chang pressure-flow scour equation (oral communication, J. Sterling Jones, October 4, 1996). Therefore, contraction scour for all discharges was computed by use of the Chang equation (Richardson and others, 1995, p. 145-146). For comparison, estimates of contraction scour were also computed by use of the Laursen clear-water contraction scour equation and presented in Appendix F. In this case, the 500-year model resulted in the worst case contraction scour with a scour depth of $0.8 \mathrm{ft}$. However, it was not the worst-case total scour. The streambed armoring depths computed suggest that armoring will not limit the depth of contraction scour.

Abutment scour was computed by use of the Froehlich equation (Richardson and others, 1995, p. 48, equation 28). Variables for the Froehlich equation include the Froude number of the flow approaching the embankments, the length of the embankment blocking flow, and the depth of flow approaching the embankment less any roadway overtopping. 


\section{Scour Results}

Contraction scour:

Main channel

Live-bed scour

Clear-water scour

Depth to armoring

Left overbank

Right overbank

Local scour:

Abutment scour

Left abutment

\section{Right abutment}

Pier scour

Pier 1

Pier 2

Pier 3

Abutments:

Left abutment

Right abutment

Piers:

Pier 1

Pier 2

100-yr discharge 500-yr discharge

(Scour depths in feet)

9.5

11.0

11.2

10.6

8.9-

$10.8-$

overtopping discharge
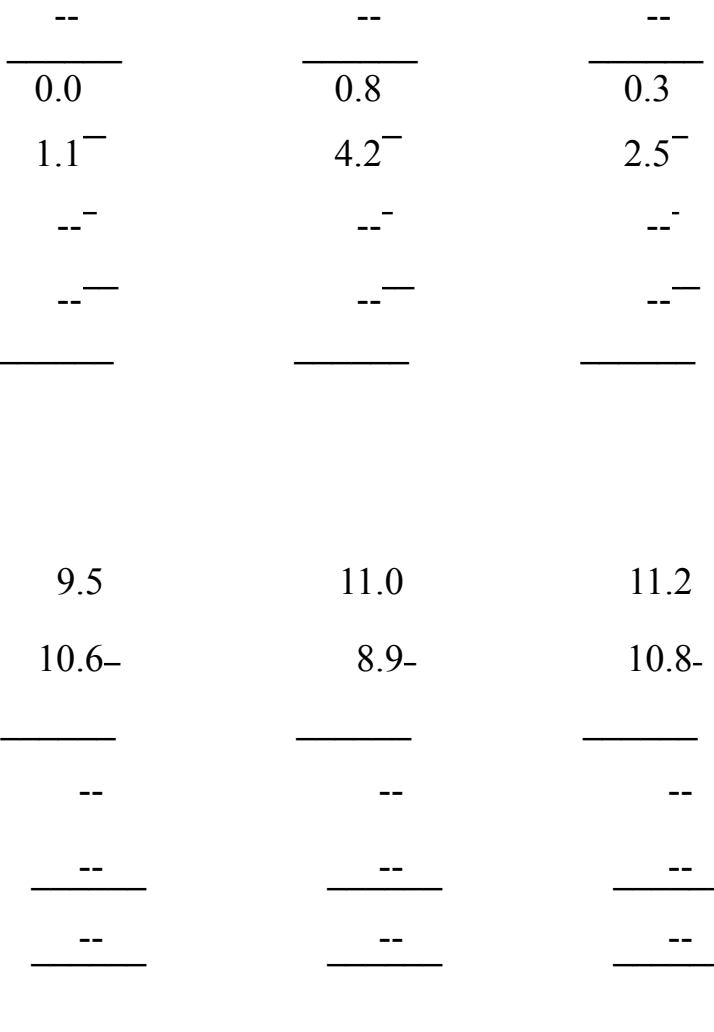

Riprap Sizing

Incipient overtopping 100-yrdischarge 500-yrdischarge discharge

\begin{tabular}{ccc} 
& $\left(D_{50}\right.$ in feet $)$ & \\
2.5 & 3.5 & 3.2 \\
2.5 & 3.5 & 3.2 \\
\cline { 2 - 3 }-- & -- & -- \\
-- & -- & -- \\
-- & -- & -- \\
\hline
\end{tabular}




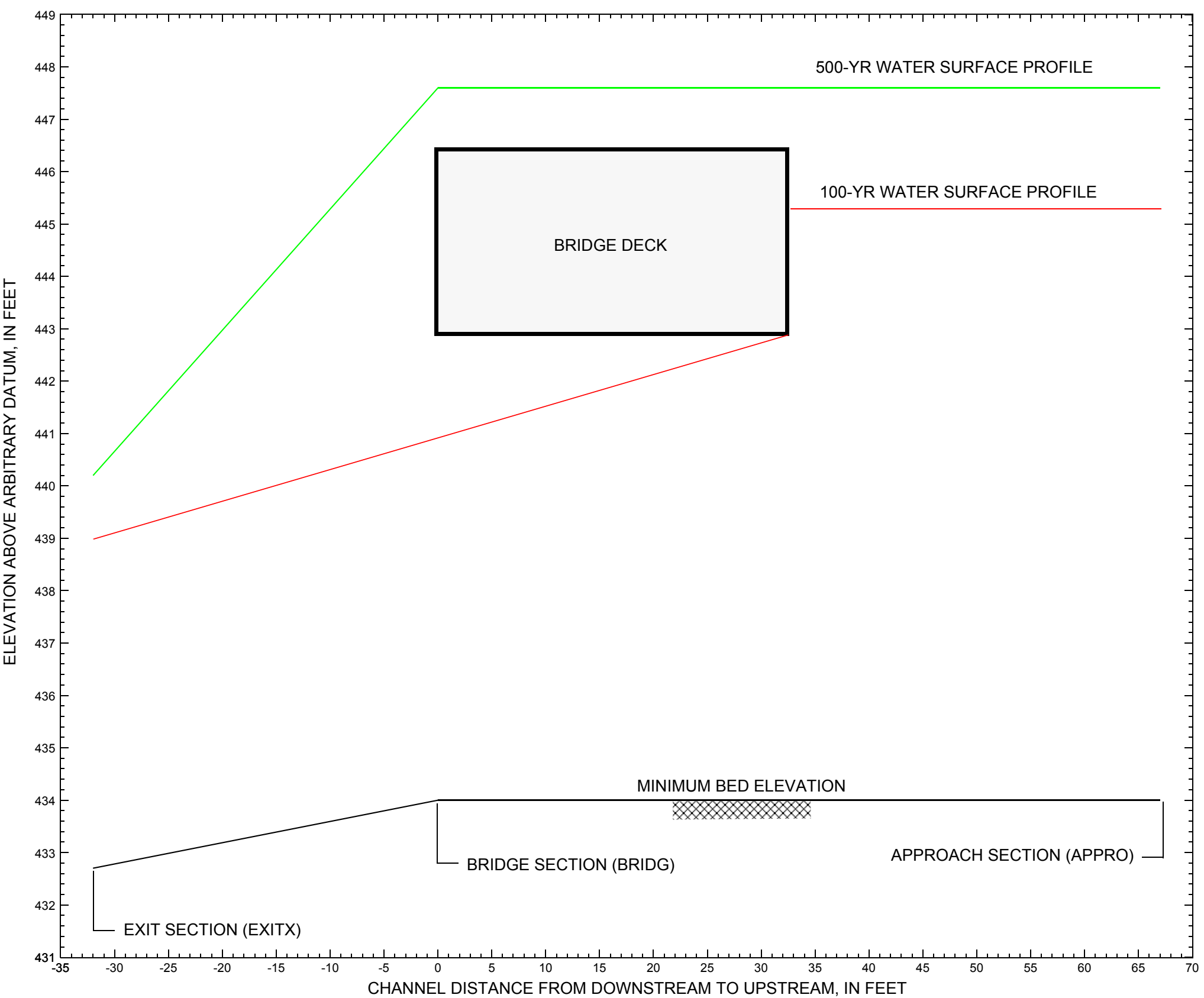

Figure 7. Water-surface profiles for the 100- and 500-yr discharges at structure ANDOVT00110039 on State Route 11, crossing the Middle Branch Williams River, Andover, Vermont. 


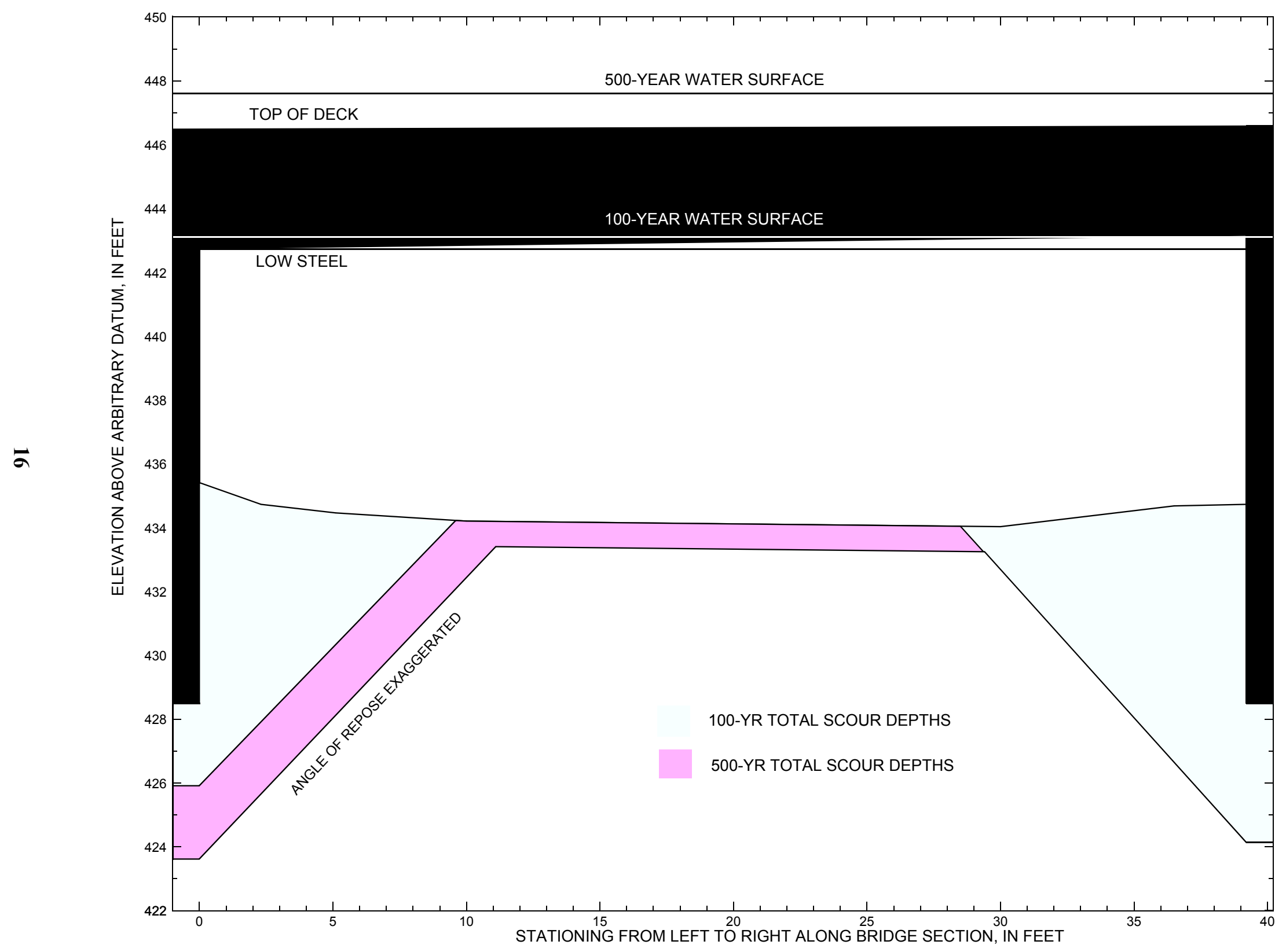

Figure 8. Scour elevations for the 100-yr and 500-yr discharges at structure ANDOVT00110039 on State Route 11, crossing the Middle Branch Williams River, Andover, Vermont. 
Table 1. Remaining footing/pile depth at abutments for the 100-year discharge at structure ANDOVT00110039 on State Route 11, crossing the Middle Branch Williams River, Andover, Vermont.

[VTAOT, Vermont Agency of Transportation; --, no data]

\begin{tabular}{|c|c|c|c|c|c|c|c|c|c|c|c|}
\hline Description & Station $^{1}$ & $\begin{array}{l}\text { VTAOT } \\
\text { minimum } \\
\text { bridge seat } \\
\text { elevation } \\
\text { (feet) }\end{array}$ & $\begin{array}{l}\text { Surveyed } \\
\text { minimum } \\
\text { low-chord } \\
\text { elevation } \\
\quad \text { (feet) }\end{array}$ & $\begin{array}{l}\text { Bottom of } \\
\text { footing } \\
\text { elevation } \\
\text { (feet) }\end{array}$ & $\begin{array}{c}\text { Channel } \\
\text { elevation at } \\
\text { abutment/ } \\
\text { pier }^{2} \\
\text { (feet) }\end{array}$ & $\begin{array}{l}\text { Contraction } \\
\text { scour depth } \\
\text { (feet) }\end{array}$ & $\begin{array}{l}\text { Abutment } \\
\text { scour } \\
\text { depth } \\
\text { (feet) }\end{array}$ & $\begin{array}{l}\text { Pier } \\
\text { scour } \\
\text { depth } \\
\text { (feet) }\end{array}$ & $\begin{array}{l}\text { Depth of } \\
\text { total scour } \\
\text { (feet) }\end{array}$ & $\begin{array}{c}\text { Elevation of } \\
\text { scour }^{2} \\
\text { (feet) }\end{array}$ & $\begin{array}{l}\text { Remaining } \\
\text { footing/pile } \\
\text { depth } \\
\text { (feet) }\end{array}$ \\
\hline \multicolumn{12}{|c|}{100 -yr. discharge is 1,980 cubic-feet per second } \\
\hline Left abutment & 0.0 & 391.8 & 442.7 & 428.4 & 435.4 & 0.0 & 9.5 & -- & 9.5 & 425.9 & -2.5 \\
\hline Right abutment & 39.2 & -- & 443.1 & 428.4 & 434.7 & 0.0 & 10.6 & -- & 10.6 & 424.1 & -4.3 \\
\hline
\end{tabular}

1.Measured along the face of the most constricting side of the bridge.

2.Arbitrary datum for this study.

Table 2. Remaining footing/pile depth at abutments for the 500-year discharge at structure ANDOVT00110039 on State Route 11, crossing the Middle Branch Williams River, Andover, Vermont.

[VTAOT, Vermont Agency of Transportation; --, no data]

\begin{tabular}{|c|c|c|c|c|c|c|c|c|c|c|c|}
\hline Description & Station $^{1}$ & $\begin{array}{l}\text { VTAOT } \\
\text { minimum } \\
\text { bridge seat } \\
\text { elevation } \\
\text { (feet) }\end{array}$ & $\begin{array}{c}\text { Surveyed } \\
\text { minimum } \\
\text { low-chord } \\
\text { elevation } \\
\text { (feet) }\end{array}$ & $\begin{array}{c}\text { Bottom of } \\
\text { footing } \\
\text { elevation } \\
\text { (feet) }\end{array}$ & $\begin{array}{c}\text { Channel } \\
\text { elevation at } \\
\text { abutment/ } \\
\text { pier }^{2} \\
\text { (feet) }\end{array}$ & $\begin{array}{l}\text { Contraction } \\
\text { scour depth } \\
\text { (feet) }\end{array}$ & $\begin{array}{l}\text { Abutment } \\
\text { scour } \\
\text { depth } \\
\text { (feet) }\end{array}$ & $\begin{array}{l}\text { Pier } \\
\text { scour } \\
\text { depth } \\
\text { (feet) }\end{array}$ & $\begin{array}{l}\text { Depth of } \\
\text { total scour } \\
\text { (feet) }\end{array}$ & $\begin{array}{c}\text { Elevation of } \\
\text { scour }^{2} \\
\text { (feet) }\end{array}$ & $\begin{array}{c}\text { Remaining } \\
\text { footing/pile } \\
\text { depth } \\
\text { (feet) }\end{array}$ \\
\hline \multicolumn{12}{|c|}{500 -yr. discharge is 2,900 cubic-feet per second } \\
\hline Left abutment & 0.0 & 391.8 & 442.7 & 428.4 & 435.4 & 0.8 & 11.0 & -- & 11.8 & 423.6 & -4.8 \\
\hline Right abutment & 39.2 & -- & 443.1 & 428.4 & 434.7 & 0.8 & 8.9 & -- & 9.7 & 425.0 & -3.4 \\
\hline
\end{tabular}

1.Measured along the face of the most constricting side of the bridge.

2.Arbitrary datum for this study. 


\section{SELECTED REFERENCES}

Arcement, G.J., Jr., and Schneider, V.R., 1989, Guide for selecting Manning's roughness coefficients for natural channels and flood plains:

U.S. Geological Survey Water-Supply Paper 2339, 38 p.

Barnes, H.H., Jr., 1967, Roughness characteristics of natural channels: U.S. Geological Survey Water-Supply Paper 1849,213 p.

Benson, M. A., 1962, Factors Influencing the Occurrence of Floods in a Humid Region of Diverse Terrain: U.S. Geological Survey WaterSupply Paper 1580-B, 64 p.

Brown, S.A. and Clyde, E.S., 1989, Design of riprap revetment: Federal Highway Administration Hydraulic Engineering Circular No. 11, Publication FHWA-IP-89-016, 156 p.

Federal Highway Administration, 1983, Runoff estimates for small watersheds and development of sound design: Federal Highway Administration Report FHWA-RD-77-158.

Federal Highway Administration, 1993, Stream Stability and Scour at Highway Bridges: Participant Workbook: Federal Highway Administration Report FHWA-HI-91-011.

Federal Emergency Management Agency, 1982, Flood Insurance Study, Town of Chester, Windsor County, Vermont: Washington, D.C., February 1982.

Froehlich, D.C., 1989, Local scour at bridge abutments in Ports, M.A., ed., Hydraulic Engineering--Proceedings of the 1989 National Conference on Hydraulic Engineering: New York, American Society of Civil Engineers, p. 13-18.

Hayes, D.C.,1993, Site selection and collection of bridge-scour data in Delaware, Maryland, and Virginia: U.S. Geological Survey WaterResources Investigation Report 93-4017, 23 p.

Interagency Advisory Committee on Water Data, 1982, Guidelines for determining flood flow frequency: U.S. Geological Survey, Bulletin 17B of the Hydrology Subcommittee, 190 p.

Johnson, C.G. and Tasker, G.D.,1974, Progress report on flood magnitude and frequency of Vermont streams: U.S. Geological Survey OpenFile Report 74-130, 37 p.

Lagasse, P.F., Schall, J.D., Johnson, F., Richardson, E.V., Chang, F., 1995, Stream Stability at Highway Structures: Federal Highway Administration Hydraulic Engineering Circular No. 20, Publication FHWA-IP-90-014, 144 p.

Laursen, E.M., 1960, Scour at bridge crossings: Journal of the Hydraulics Division, American Society of Civil Engineers, v. 86, no. HY2, p. 39-53.

Potter, W. D., 1957a, Peak rates of runoff in the Adirondack, White Mountains, and Maine woods area, Bureau of Public Roads

Potter, W. D., 1957b, Peak rates of runoff in the New England Hill and Lowland area, Bureau of Public Roads

Richardson, E.V. and Davis, S.R., 1995, Evaluating scour at bridges: Federal Highway Administration Hydraulic Engineering Circular No. 18, Publication FHWA-IP-90-017, 204 p.

Richardson, E.V., Simons, D.B., and Julien, P.Y., 1990, Highways in the river environment: Federal Highway Administration Publication FHWA-HI-90-016.

Ritter, D.F., 1984, Process Geomorphology: W.C. Brown Co., Debuque, Iowa, 603 p.

Shearman, J.O., 1990, User's manual for WSPRO--a computer model for water surface profile computations: Federal Highway Administration Publication FHWA-IP-89-027, 187 p.

Shearman, J.O., Kirby, W.H., Schneider, V.R., and Flippo, H.N., 1986, Bridge waterways analysis model; research report: Federal Highway Administration Publication FHWA-RD-86-108, 112 p.

Talbot, A.N., 1887, The determination of water-way for bridges and culverts.

U.S. Department of Transportation, 1993, Stream stability and scour at highway bridges, Participant Workbook: Federal Highway Administration Publication FHWA HI-91-011.

U.S. Geological Survey, 1971, Andover, Vermont 7.5 Minute Series quadrangle map: U.S. Geological Survey Topographic Maps, Scale $1: 24,000$. 


\section{APPENDIX A: \\ WSPRO INPUT FILE}




\section{APPENDIX B: \\ WSPRO OUTPUT FILE}


WSPRO OUTPUT FILE

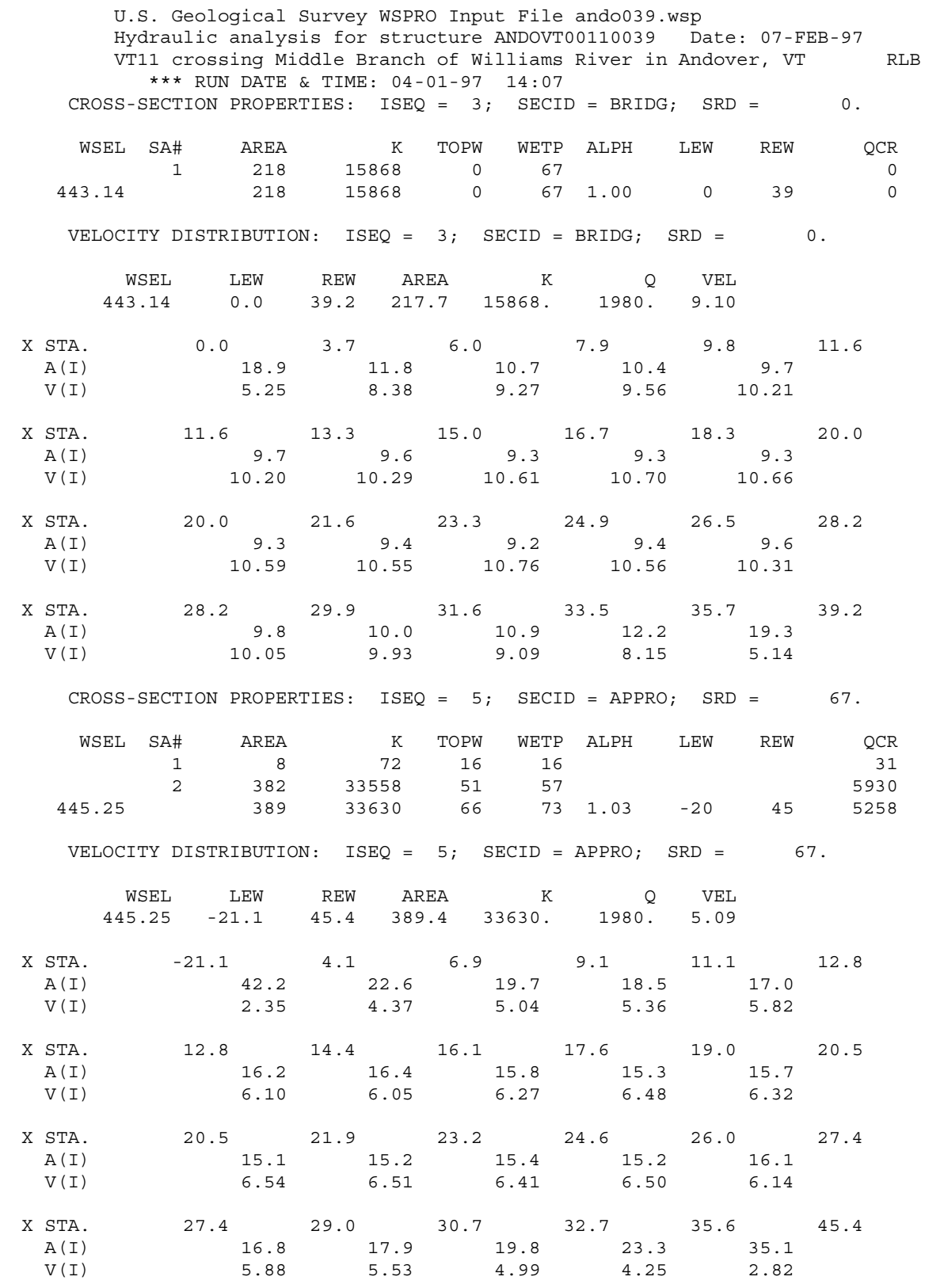


WSPRO OUTPUT FILE (continued)

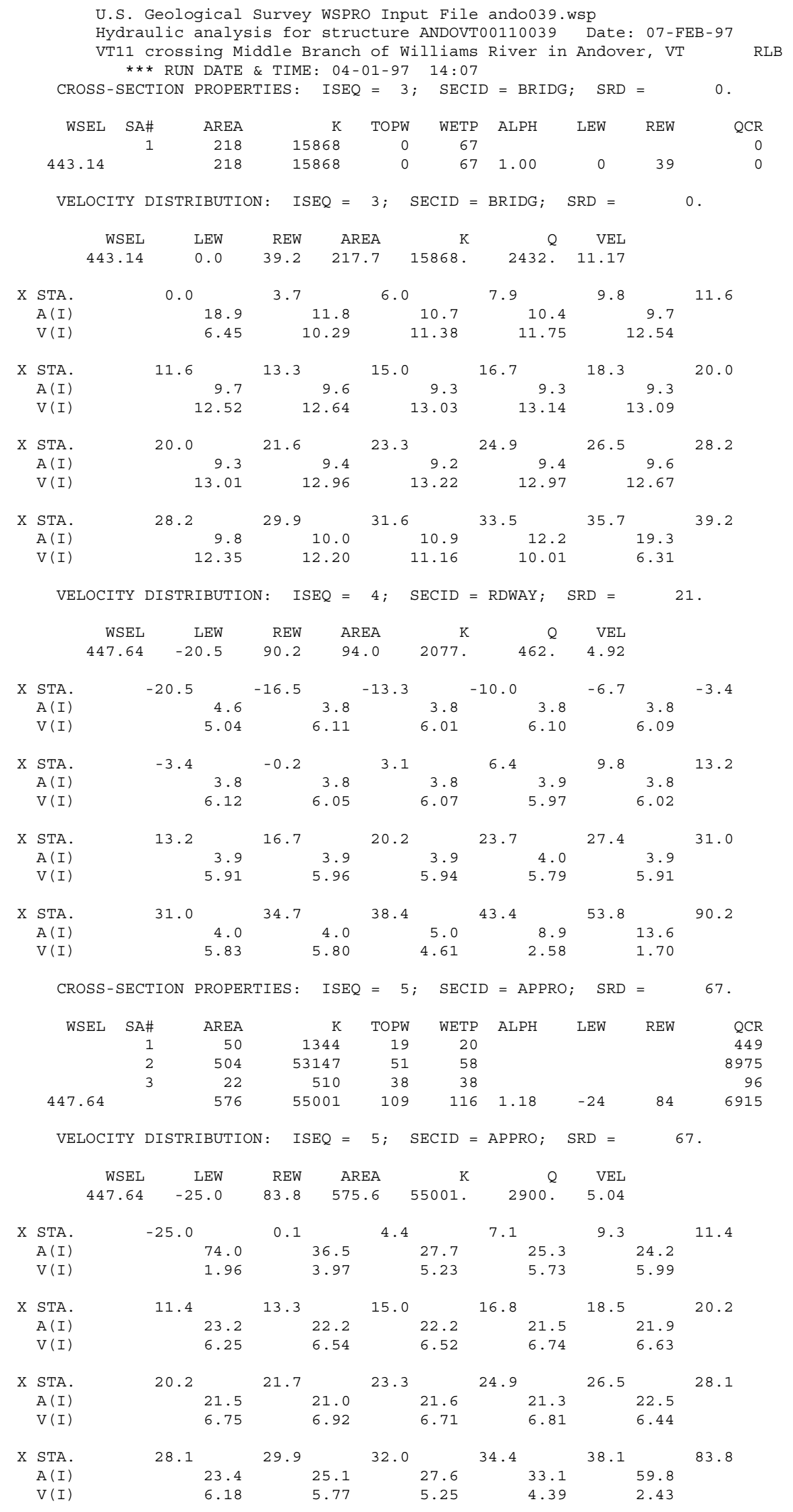


WSPRO OUTPUT FILE (continued)

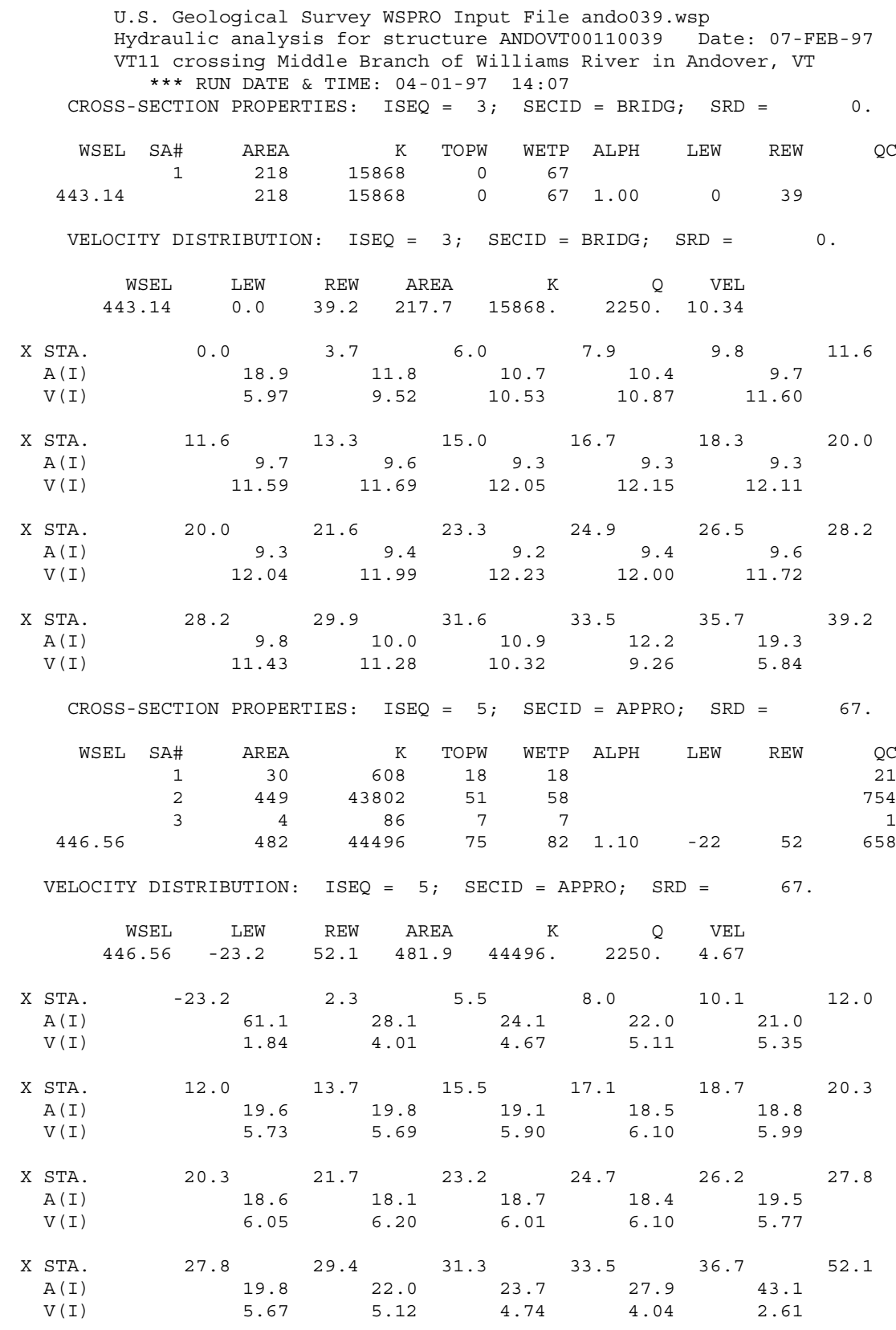


WSPRO OUTPUT FILE (continued)

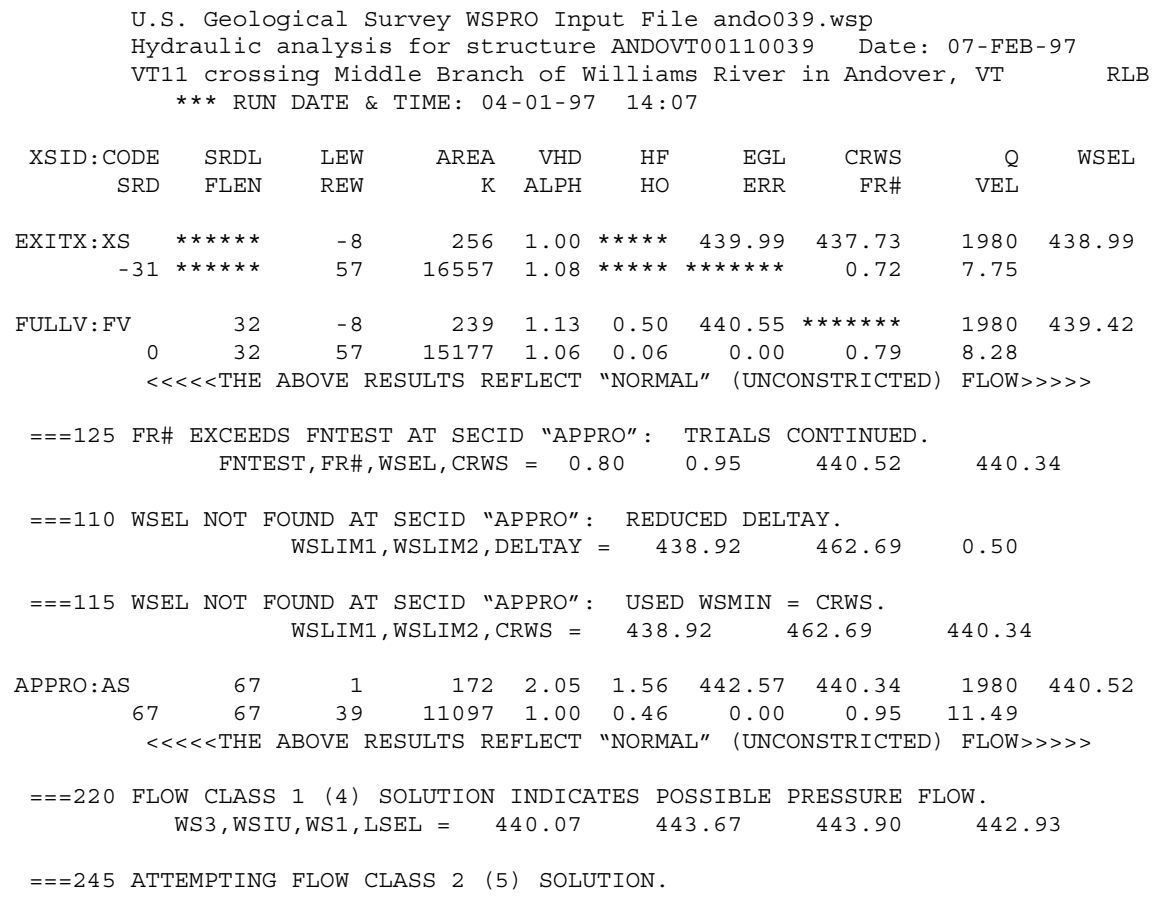


WSPRO OUTPUT FILE (continued)

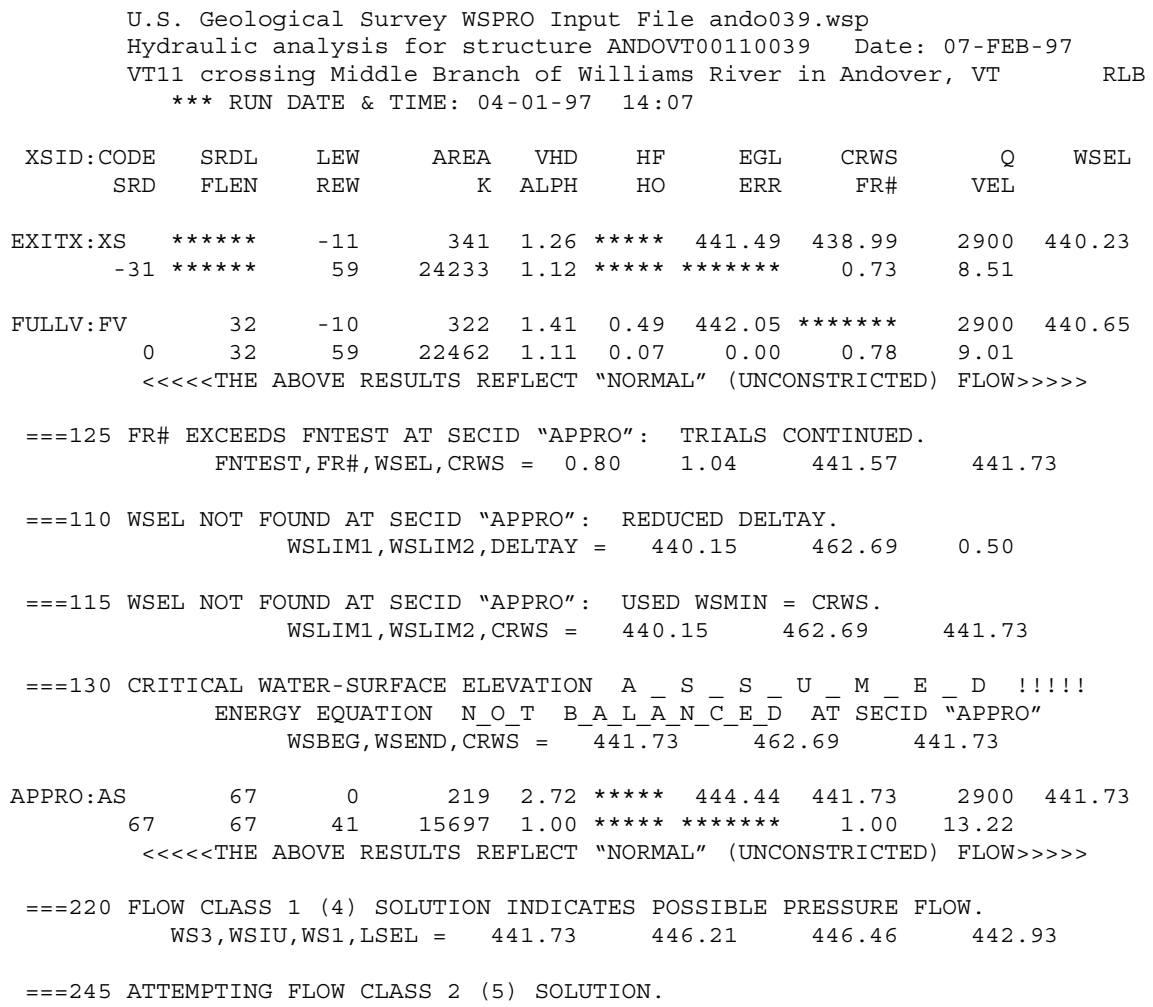

FIRST USER DEFINED TABLE.

\begin{tabular}{|c|c|c|c|c|c|c|c|c|}
\hline XSID:CODE & SRD & LEW & REW & $Q$ & K & AREA & VEL & WSEL \\
\hline EXITX:XS & -32 & -12 & 59. & 2900. & 24233 . & 341 . & 8.51 & 440.23 \\
\hline FULLV : FV & 0 & -11 & 59. & 2900 . & 22462 . & 322 . & 9.01 & 440.65 \\
\hline BRIDG : BR & 0. & 0 . & 39. & 2432 . & 15868. & 218 . & 11.18 & 443.14 \\
\hline RDWAY : RG & 21 . * & $* \star \star \star \star *$ & 228 . & 462. & 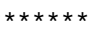 & 0 . & 1.00 & 447.64 \\
\hline APPRO:AS & 67. & -25 & 84. & 2900. & 54975. & 575. & 5.04 & 447.64 \\
\hline XSID : CODE & XLKQ & XRKQ & & & & & & \\
\hline
\end{tabular}

SECOND USER DEFINED TABLE.

\begin{tabular}{|c|c|c|c|c|c|c|c|c|c|}
\hline $\mathrm{CODE}$ & CRWS & FR\# & MIN & YMAX & $\mathrm{HF}$ & $\mathrm{HO}$ & VHD & EGL & \\
\hline XXIT & & 73 & 32.65 & 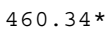 & $* \star * \star *$ & & 1.26 & .49 & \\
\hline UL & * & & & 2 & 0.49 & 0.07 & 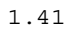 & 5 & \\
\hline - & & & & -4 * & 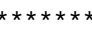 & $\star \star \star \star * *$ & 94 & 8 & \\
\hline & & $\star \star \star * *$ & & 3.12 & 0 & $\star \star \star \star \star *$ & 47 & .01 & \\
\hline $0: A S$ & 441.73 & 0.42 & 34.01 & 462.69 & 0.18 & 1.40 & .47 & 448.10 & 47 \\
\hline
\end{tabular}


WSPRO OUTPUT FILE (continued)

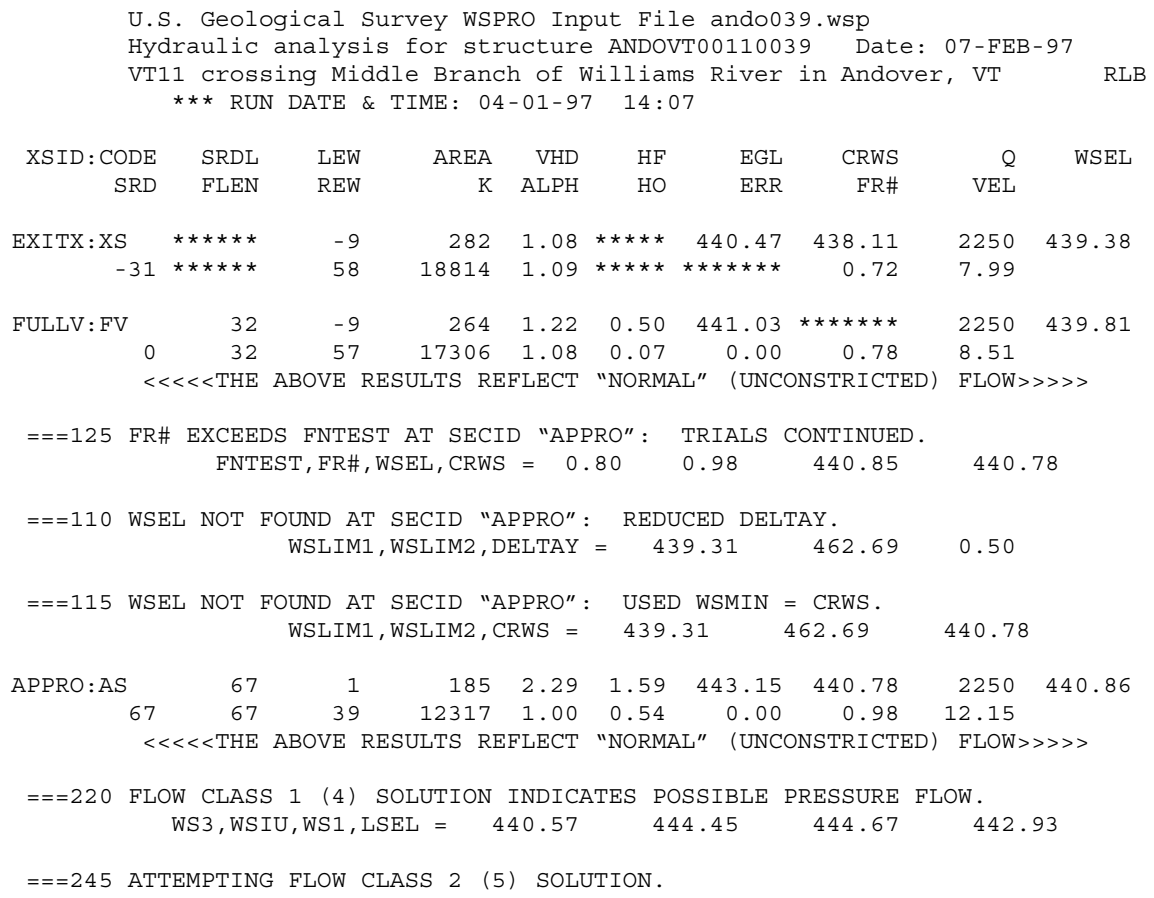

FIRST USER DEFINED TABLE.

\begin{tabular}{|c|c|c|c|c|c|c|c|c|}
\hline XSID : CODE & SRD & LEW & REW & $Q$ & $\mathrm{~K}$ & AREA & VEL & WSEL \\
\hline EXITX:XS & -32. & -10 & 58. & 2250 . & 18814. & 282 . & 7.99 & 439.38 \\
\hline FULLV : FV & 0. & -10 & 57. & 2250 . & 17306. & 264 & 8.51 & 439.81 \\
\hline BRIDG : BR & 0 . & 0 . & 39. & 2242 . & 15868. & 218 & 10.30 & 443.14 \\
\hline RDWAY : RG & 21 .* & $* * * * *$ & $* * *$ & 0 . & 0 . & 0. & $1.00 *$ & 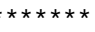 \\
\hline APPRO : AS & 67. & -23 & 52. & 2250 . & 44470 . & 482 . & 4.67 & 446.56 \\
\hline XSID: CODE & XLKQ & XRKQ & & & & & & \\
\hline
\end{tabular}

SECOND USER DEFINED TABLE.

\begin{tabular}{|c|c|c|c|c|c|c|c|c|c|}
\hline XSID : CODI & CRWS & FR\# & YMIN & YMAX & $\mathrm{HF}$ & $\mathrm{HO}$ & VHD & EGL & WSEL \\
\hline EXITX:XS & 438.11 & 0.72 & 432.65 & 460.34 * & $\star \star \star *$ & *** & 1.08 & 440.47 & 439.38 \\
\hline FULLV : FV & $\star \star \star \star \star \star * \star * *$ & .78 & 433.33 & 461.02 & 0.50 & 0.07 & 1.22 & 441.03 & 439.81 \\
\hline : BR & 440.57 & 0.77 & 434.03 & 443.14 & $\star \star *$ & $* * * * *$ & 1.65 & 444.79 & 443.14 \\
\hline RG & 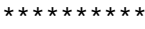 & $\star \star \star \star *$ & 446.48 & $463.12 x$ & $* * x$ & $\bar{\star}$ & 0.37 & 446.84 & $\star * *$ \\
\hline PPRO : AS & 440.78 & 0.34 & 434.01 & 462.69 & 0.13 & 1.36 & 0.37 & 446.93 & 446.56 \\
\hline
\end{tabular}




\section{APPENDIX C:}

\section{BED-MATERIAL PARTICLE-SIZE DISTRIBUTION}




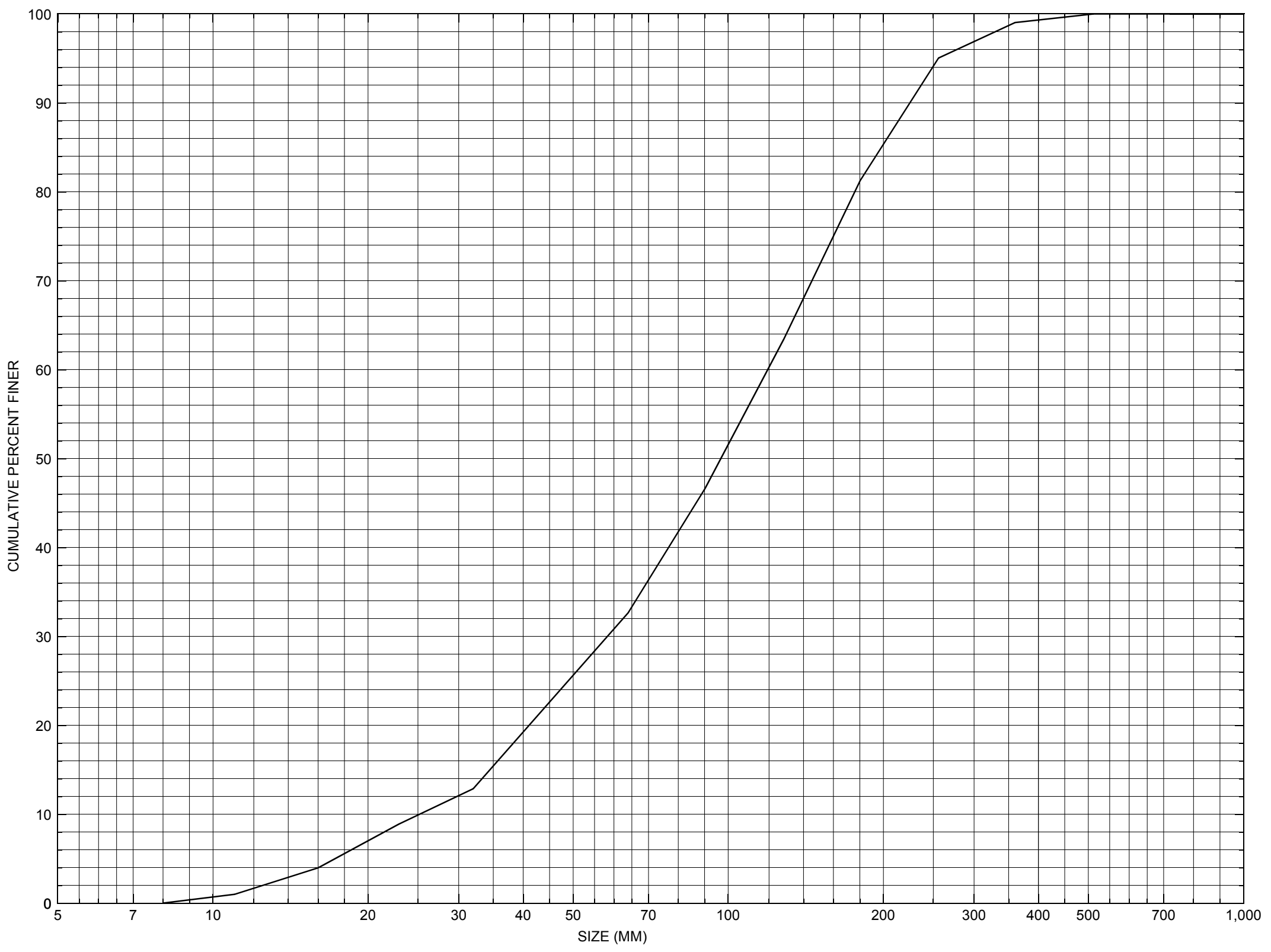

Appendix C. Bed material particle-size distribution for a pebble count in the channel approach of structure ANDOVT00110039, in Andover, Vermont. 


\section{APPENDIX D: \\ HISTORICAL DATA FORM}




\section{Structure Number ANDOVT00110039}

\section{General Location Descriptive}

Data collected by (First Initial, Full last name) M. IVANOFF

Date $(M M / D D / Y Y) \_\mathbf{0 3} / \underline{29} / \underline{95}$

Highway District Number (I - 2; nn) $\mathbf{0 2}$

Town (FIPS place code; I - 4; nnnnn) $\mathbf{0 1 3 0 0}$

Waterway (I - 6) MIDDLE BR WILLIAMS RIVER

Route Number VT 11

Topographic Map Andover

Latitude (I - 16; nnnn.n) $\mathbf{4 3 1 5 3}$
County (FIPS county code; I - 3; nnn)

Mile marker (I - 11; nnn.nnn) $\mathbf{0 0 1 6 7 0}$

Road Name (I - 7): -

Vicinity (I - 9) 3.0 MI E JCT VT 121

Hydrologic Unit Code: $\mathbf{0 1 0 8 0 1 0 7}$

Longitude (i - 17; nnnnn.n) $\mathbf{7 2 4 3 2}$

\section{Select Federal Inventory Codes}

FHWA Structure Number $(I-8) \underline{20001600391401}$

Maintenance responsibility $(I-21 ; n n) \quad \mathbf{0 1} \quad$ Maximum span length $(I-48 ; n n n n) \underline{\mathbf{0 0 4 1}}$

Year built (I - 27; YYYY) 1929

Structure length (I - 49; nnnnnn) $\underline{\mathbf{0 0 0 0 4 3}}$

Average daily traffic, ADT (I - 29; nnnnnn) $\underline{002736}$

Deck Width (I - 52; nn.n) $\mathbf{3 2 5}$

Year of ADT (I - 30; YY) $\mathbf{9 2}$

Channel \& Protection $(I-61 ; n)$

Opening skew to Roadway $(I-34 ; n n) \quad \mathbf{4 5}$

Waterway adequacy $(I-71 ; n) \underline{5}$

Operational status $(I-41 ; X) \quad \mathbf{A}$

Underwater Inspection Frequency $(I-92 B ; X Y Y) \_$N

Structure type (I - 43; nnn) 104

Year Reconstructed (I - 106) 1973

Approach span structure type (I - 44; nnn) $\mathbf{0 0 0}$ Clear span (nnn.n ft)

Number of spans (I - 45; nnn) $\mathbf{0 0 1}$

Vertical clearance from streambed (nnn.n ft) $\underline{\mathbf{8 . 0}}$

Number of approach spans (I - 46; nnnn) $\mathbf{0 0 0 0}$ Waterway of full opening (nnn.n $\left.\mathrm{ft}^{2}\right)$

Comments:

The structural inspection report of 11/10/94 indicates the structure is a concrete T-beam type bridge with an asphalt road surface. The concrete footing is exposed on the upstream end at the newer portion of the abutment. The left abutment has some minor scaling along the flow lines. The upstream right wingwall is in good condition. The downstream right wingwall has some moderate scaling along the flow line and the top of the wingwall is cracked off. The upstream left wingwall has some minor cracks and stains. The downstream left wingwall has some heavy spalling and heavily corroded reinforcement bar exposed 12 feet from the end. There is a crack, approximately 4 inches wide in the downstream (Continued, page 33) 


\section{Bridge Hydrologic Data}

Is there hydrologic data available? $\underline{\mathbf{N}}$ if No, type ctrl-n $h \quad$ VTAOT Drainage area $\left(m i^{2}\right)$ : -

Terrain character:

Stream character \& type: -

Streambed material:

Discharge Data (cfs):

$$
\begin{aligned}
& Q_{2.33}- \\
& Q_{50}-
\end{aligned}
$$

Record flood date $(M M / D D / Y Y)$ :

Estimated Discharge (cfs): Ice conditions (Heavy, Moderate, Light) : -

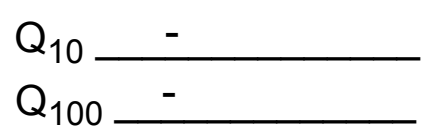

$$
\begin{aligned}
& Q_{25}- \\
& Q_{500}-
\end{aligned}
$$

Water surface elevation $(f t):-$

The stage increases to maximum highwater elevation (Rapidly, Not rapidly):

The stream response is (Flashy, Not flashy):

Describe any significant site conditions upstream or downstream that may influence the stream's stage: -

Watershed storage area (in percent): _ _ \%

The watershed storage area is: - (1-mainly at the headwaters; 2- uniformly distributed; 3-immediatly upstream oi the site)

Water Surface Elevation Estimates for Existing Structure:

\begin{tabular}{|l|l|l|l|l|l|}
\hline Peak discharge frequency & $Q_{2.33}$ & $Q_{10}$ & $Q_{25}$ & $Q_{50}$ & $Q_{100}$ \\
Water surface elevation (ft)) & - & - & - & - & - \\
Velocity (ft/sec) & - & - & - & - & - \\
\hline
\end{tabular}

Long term stream bed changes: -

Is the roadway overtopped below the $\mathrm{Q}_{100}$ ? (Yes, No, Unknown): $\mathbf{U}$ Frequency: Relief Elevation (ft): Discharge over roadway at $Q_{100}\left(f^{3} / \mathrm{sec}\right)$ :

Are there other structures nearby? (Yes, No, Unknown): $\underline{\mathbf{U}}$ Upstream distance (miles): Town: If No or Unknown, type ctrl-n os Highway No. : Structure No. : Year Built:

Clear span (ft): Clear Height $(f t)$ : Full Waterway $\left(f^{2}\right)$ : 
Downstream distance (miles): Town: Year Built:

Highway No. : Structure No. : Structure Type:

Clear span $(f t):$ Clear Height (ft): Full Waterway $\left(f^{2}\right)$ :

Comments:

left wingwall. Some areas show signs of movement. The left abutment footing is not in view. The channel alignment is straight through the skewed structure with a slight turn approximately 50 feet downstream. The channel bed consists of stone and gravel. There is some heavy stone riprap along the upstream right abutment end, and some stone and free-poured concrete at the upstream end of the left abutment. The wings have some course gravel and vegetation in front of them.

\section{USGS Watershed Data}

Watershed Hydrographic Data

Drainage area $(D A)$

Watershed storage (ST)

Bridge site elevation 1200

Main channel length 5.03 $10 \%$ channel length elevation $\mathrm{mi}^{2}$ 0 $\%$ $\mathrm{ft}$ $\mathrm{mi}$

Main channel slope (S) 229.72 1240 $\mathrm{ft} \quad 85 \%$ channel length elevation 2106

Watershed Precipitation Data

Average site precipitation in Average headwater precipitation in

Maximum 2yr-24hr precipitation event $(124,2)$ in

Average seasonal snowfall (Sn) $\mathrm{ft}$ 


\section{Bridge Plan Data}

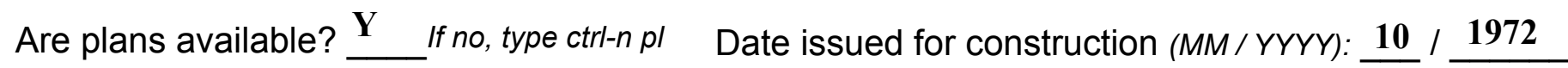
Project Number BMA 6308 Minimum channel bed elevation: $\underline{\mathbf{3 8 3 . 0}}$

Low superstructure elevation: USLAB $\underline{391.75}$ DSLAB $\underline{\mathbf{3 9 2 . 7 8} \text { USRAB - _ DSRAB } 393.04}$ Benchmark location description:

Chiseled ' $X$ ' in the concrete step to church located 115 feet left bankward from the left abutment and 58 feet perpendicular from roadway centerline in upstream direction, elevation 392.21.

Reference Point (MSL, Arbitrary, Other): Arbitrary $\quad$ Datum (NAD27, NAD83, Other): Arbitrary Foundation Type: 1 (1-Spreadfooting; 2-Pile; 3- Gravity; 4-Unknown)

If 1 : Footing Thickness $\mathbf{2 . 0} \quad$ Footing bottom elevation: 3 377.5*

If 2: Pile Type: __ (1-Wood; 2-Steel or metal; 3-Concrete) Approximate pile driven length:

If 3: Footing bottom elevation:

Is boring information available? $\mathbf{N}$ If no, type ctrl- $n$ bi Number of borings taken: _-

Foundation Material Type: $\mathbf{3}$ (1-regolith, 2-bedrock, 3-unknown)

Briefly describe material at foundation bottom elevation or around piles:

Plans show "bottom of footings foundation: boulder"

Comments:

*The base of the new upstream right wing wall is 381.0 with a top elevation of 395.56 . The original structure remained during the rehabilitation in 1972 which included only widening the deck on the upstream side. Other elevation points: 1) point on the top streamward edge of the upstream right wingwall where it meets the right abutment, elevation $395.56 ; 2$ ) the point at the upstream end of the upstream left wingwall on the top streamward corner of the concrete, elevation 391.0. The footings on the widened section are shown with a bottom elevation about 3.5 feet higher than those on the original bridge set at 377.5 . The bed elevation on the original structure is shown at 383.0. 


\section{Cross-sectional Data}

Is cross-sectional data available? $\mathbf{N}$ If no, type ctrl-n xs

Source (FEMA, VTAOT, Other)? -

Comments: NO CROSS SECTION INFORMATION

\begin{tabular}{|l|l|l|l|l|l|l|l|l|l|l|l|}
\hline Station & - & - & - & - & - & - & - & - & - & - & - \\
\hline Feature & - & - & - & - & - & - & - & - & - & - & - \\
\hline $\begin{array}{l}\text { Low cord } \\
\text { elevation }\end{array}$ & - & - & - & - & - & - & - & - & - & - & - \\
\hline $\begin{array}{l}\text { Bed } \\
\text { elevation }\end{array}$ & - & - & - & - & - & - & - & - & - & - & - \\
\hline $\begin{array}{l}\text { Low cord to } \\
\text { bed length }\end{array}$ & - & - & - & - & - & - & - & - & - & - & - \\
\hline Station & - & - & - & - & - & - & - & - & - & - & - \\
\hline Feature & - & - & - & - & - & - & - & - & - & - & - \\
\hline $\begin{array}{l}\text { Low cord } \\
\text { elevation }\end{array}$ & - & - & - & - & - & - & - & - & - & - & - \\
\hline $\begin{array}{l}\text { Bed } \\
\text { elevation }\end{array}$ & - & - & - & - & - & - & - & - & - & - & - \\
\hline $\begin{array}{l}\text { Low cord to } \\
\text { bed length }\end{array}$ & - & - & - & - & - & - & - & - & - & - & - \\
\hline
\end{tabular}

Source (FEMA, VTAOT, Other)?

Comments: NO CROSS SECTION INFORMATION

\begin{tabular}{|l|l|l|l|l|l|l|l|l|l|l|l|}
\hline Station & - & - & - & - & - & - & - & - & - & - & - \\
\hline Feature & - & - & - & - & - & - & - & - & - & - & - \\
\hline $\begin{array}{l}\text { Low cord } \\
\text { elevation }\end{array}$ & - & - & - & - & - & - & - & - & - & - & - \\
\hline $\begin{array}{l}\text { Bed } \\
\text { elevation }\end{array}$ & - & - & - & - & - & - & - & - & - & - & - \\
\hline $\begin{array}{l}\text { Low cord to } \\
\text { bed length }\end{array}$ & - & - & - & - & - & - & - & - & - & - & - \\
\hline Station & - & - & - & - & - & - & - & - & - & - & - \\
\hline Feature & - & - & - & - & - & - & - & - & - & - & - \\
\hline $\begin{array}{l}\text { Low cord } \\
\text { elevation }\end{array}$ & - & - & - & - & - & - & - & - & - & - & - \\
\hline $\begin{array}{l}\text { Bed } \\
\text { elevation }\end{array}$ & - & - & - & - & - & - & - & - & - & - & - \\
\hline $\begin{array}{l}\text { Low cord to } \\
\text { bed length }\end{array}$ & - & - & - & - & - & - & - & - & - & - & - \\
\hline
\end{tabular}




\section{APPENDIX E: \\ LEVEL I DATA FORM}


U. S. Geological Survey

Bridge Field Data Collection and Processing Form

Qa/Qc Check by: $\underline{\mathbf{R B}}$ Date: 10/01/96

\section{Structure Number}

ANDOVT00110039

Computerized by: $\underline{\mathbf{R B}}$ Date: $10 / 01 / 96$

Reviewd by: $\quad$ RB Date: $\underline{\mathbf{0 3 / 3 1 / 9 7}}$

\section{A. General Location Descriptive}

1. Data collected by (First Initial, Full last name) E. WILD

2. Highway District Number $\mathbf{0 2}$

Mile marker $\mathbf{0 0 1 6 7 0}$

County 027

Waterway (I - 6) MIDDLE BR. WILLIAMS RIVER

Town ANDOVER 01300

Route Number VT 11

Road Name -

Hydrologic Unit Code: $\mathbf{0 1 0 8 0 1 0 7}$

3. Descriptive comments:

Located 3.0 miles east of the junction with VT 121 and approximately 0.1 miles west of Lyman Brook junction with the Middle Branch of the Williams River at ANDO040.

\section{B. Bridge Deck Observations}
4. Surface cover... LBUS 6
RBUS 5
LBDS 5
RBDS 6
Overall 6

(2b us,ds,lb,rb: 1- Urban; 2- Suburban; 3- Row crops; 4- Pasture; 5- Shrub- and brushland; 6- Forest; 7- Wetland)
5. Ambient water surface... US 2
UB 2
DS 2
(1- pool; 2- riffle)

6. Bridge structure type 1 (1- single span; 2- multiple span; 3- single arch; 4- multiple arch; 5-cylindrical culvert; 6- box culvert; or 7- other)
7. Bridge length $\mathbf{4 3}$
(feet)
Span length $\underline{41}$
(feet)
Bridge width $\underline{\mathbf{3 2 . 5}}$ (feet)

\section{Road approach to bridge:}
8. LB 1
RB 2
( 0 even, 1- lower, 2- higher)
9. LB RB 1
(1- Paved, 2- Not paved)

10. Embankment slope (run / rise in feet / foot)

US left 11:4:1

US right 12:9:1

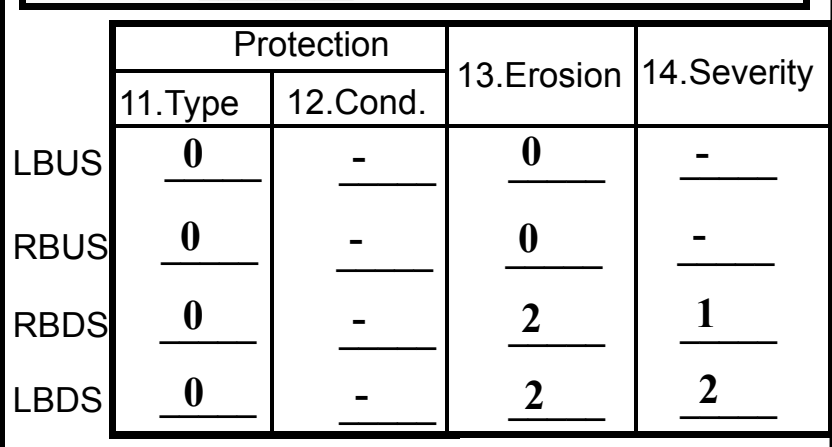

Bank protection types: 0- none; 1- $<12$ inches;

2- < 36 inches; 3- < 48 inches;

4- < 60 inches; 5- wall / artificial levee

Bank protection conditions: 1- good; 2- slumped;

3- eroded; 4- failed

Erosion: 0 - none; 1- channel erosion; 2 -

road wash; 3- both; 4- other

Erosion Severity: 0 - none; 1- slight; 2- moderate; 3- severe

\section{Channel approach to bridge (BF):}

15. Angle of approach: $\mathbf{2 0}$

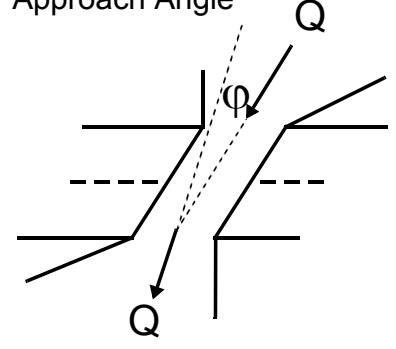

17. Channel impact zone 1 :

Where? LB $(L B, R B)$

Range? 165 feet $\underline{\text { US }}$

Channel impact zone 2:

Where? RB (LB, RB)

Range? 46 feet DS (US, UB, DS) to $\underline{150}$ feet DS

Impact Severity: 0- none to very slight; 1- Slight; 2- Moderate; 3- Severe
16. Bridge skew: 45

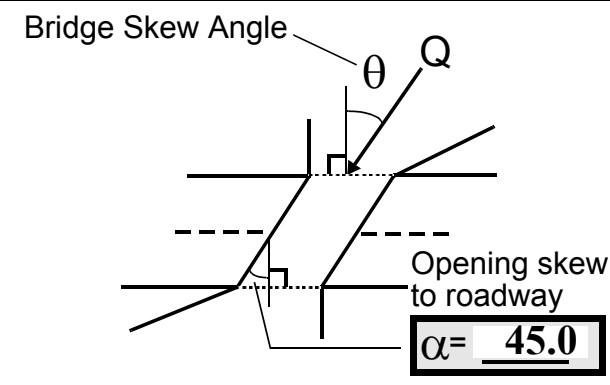

Exist? $\underline{\mathbf{Y}}(\mathrm{Y}$ or $N)$

Severity 1

US, UB, DS) to $\underline{\mathbf{0} \quad \text { feet } \underline{\mathbf{U S}}}$

Exist? $\mathbf{Y}(\mathrm{Y}$ or $N)$

Severity 1 
18. Bridge Type: 1

1a- Vertical abutments with wingwalls

$1 \mathrm{~b}$ - Vertical abutments without wingwalls

2- Vertical abutments and wingwalls, sloping embankment Wingwalls perpendicular to abut. face

3- Spill through abutments

4- Sloping embankment, vertical wingwalls and abutments

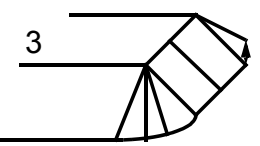

$1 \mathrm{~b}$ without wingwalls

Wingwall angle less than $90^{\circ}$.

19. Bridge Deck Comments (surface cover variations, measured bridge and span lengths, bridge type variations, approach overflow width, etc.)

4. On the left bank US a dirt driveway runs parallel to the channel. On the right bank US and the left bank DS, VT 11 runs parallel to the channel. The right bank DS is all forested.

7. Values are from the VT AOT files. Measured bridge length is $46 \mathrm{ft}$. US and $44 \mathrm{ft}$. DS, clear span length is $43.5 \mathrm{ft}$. US and $42 \mathrm{ft}$. DS, and the bridge width is $31.6 \mathrm{ft}$.

13. The road wash on the right bank DS is minor with the back side of the DS right wingwall being eroded a bit. On the left bank DS the road wash has eroded asphalt and the DS left wingwall. A large section of the DS left wingwall is hanging over the channel by rebar.

18. The US right wingwall is type 1 a and the US left wingwall slopes to $1 \mathrm{ft}$. below the low chord and is type 4 . The DS right wingwall is type 2 and the DS left wingwall is type 4.

\section{Upstream Channel Assessment}

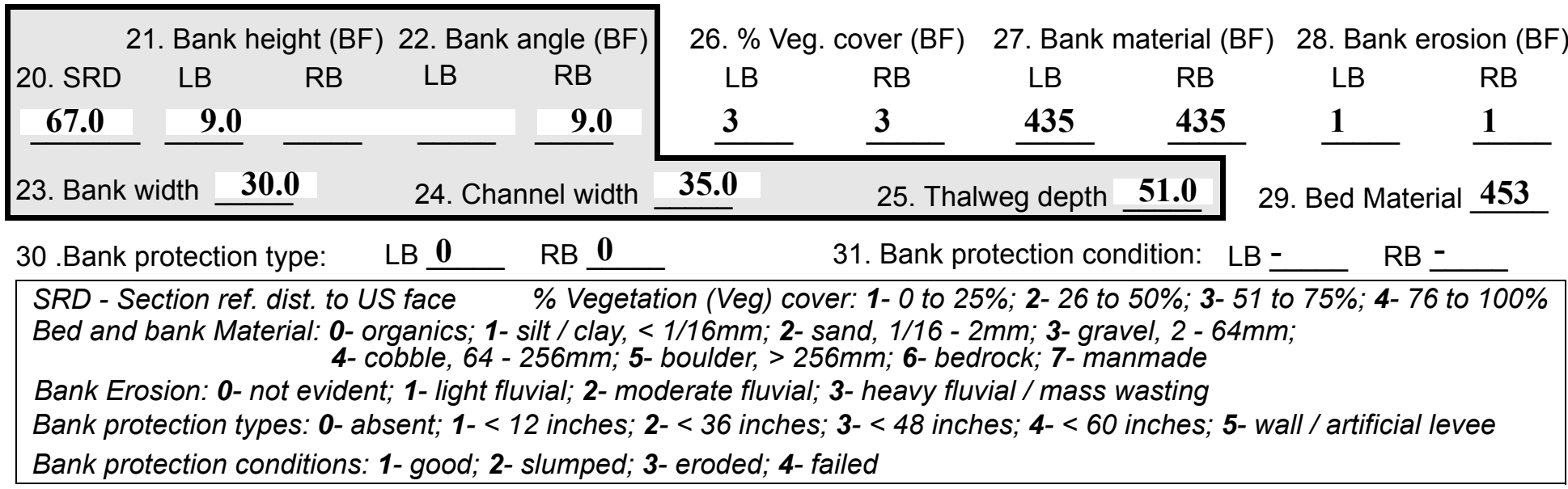

32. Comments (bank material variation, minor inflows, protection extent, etc.):

26. From $50 \mathrm{ft}$. US to the US bridge face the percent vegetation on the US right bank is $0 \%$ to $25 \%$. 
33.Point/Side bar present? $\mathbf{Y}$

$(Y$ or $N$. if $N$ type ctrl-n pb)34. Mid-bar distance: 75

35. Mid-bar width: 9.5

36. Point bar extent: $\underline{\mathbf{1 2 1}}$ feet $\underline{\mathbf{U S}}$ (US, UB) to $\underline{\mathbf{8}}$ feet $\underline{\mathbf{U S}}$ (US, UB, DS) positioned $\underline{\mathbf{0}} \%$ LB to $\underline{\mathbf{5 0}} \%$ RB

37. Material: 430

38. Point or side bar comments (Circle Point or Side; Note additional bars, material variation, status, etc.):

Vegetation on side bar is grass.

39. Is a cut-bank present? $\mathbf{Y}$ ( $Y$ or if $N$ type ctrl-n $c b)$

40. Where? $\underline{\text { LB }}$ (LB or RB)

41. Mid-bank distance: 141

42. Cut bank extent: $\underline{\mathbf{1 6 5}}$ feet $\underline{\mathbf{U S}}$ (US, UB) to $\underline{\mathbf{1 2 4}}$ feet $\underline{\mathbf{U S}}$ (US, UB, DS)

43. Bank damage: 2

(1- eroded and/or creep; 2- slip failure; 3- block failure)

44. Cut bank comments (eg. additional cut banks, protection condition, etc.):

Vegetation has slipped down the slope of the US left bank where it now protrudes into part of the channel, also

the US right bank at this point is eroded and undermined.

45. Is channel scour present? $\mathbf{N}$ ( $Y$ or if $N$ type ctrl-n cs) 46. Mid-scour distance: -

47. Scour dimensions: Length - W Width - Depth : _ _ Position - _ \% $\%$ LB to - $\%$ RB

48. Scour comments (eg. additional scour areas, local scouring process, etc.):

NO CHANNEL SCOUR

Some small scour holes are behind the boulders in the stream.

49. Are there major confluences? $\mathbf{N}$

51. Confluence 1: Distance -

Confluence 2: Distance -

52. Enters on -

Enters on -

54. Confluence comments (eg. confluence name):

NO MAJOR CONFLUENCES
50. How many? -

53. Type(1- perennial; 2- ephemeral)

Type (1- perennial; 2- ephemeral)

\section{Under Bridge Channel Assessment}

55. Channel restraint (BF)? LB 2

\begin{tabular}{|ccccc}
\hline \multicolumn{2}{|c}{ 56. Height (BF) } & \multicolumn{3}{c}{57 Angle (BF) } \\
LB & RB & & LB & RB \\
$\mathbf{2 2 . 0}$ & & & $\mathbf{0 . 5}$ & \\
\hline
\end{tabular}
(1- natural bank; 2- abutment; 3- artificial levee)

58. Bank width (BF) -

59. Channel width (Amb) -

61. Material (BF)

LB RB

$\underline{2} \quad \underline{7}$
62. Erosion (BF)

LB RB

7

60. Thalweg depth (Amb) $\mathbf{9 0 . 0}$
63. Bed Material -

Bed and bank Material: 0- organics; 1- silt / clay, < 1/16mm; 2- sand, 1/16 - 2mm; 3- gravel, 2 - 64mm; 4- cobble, 64 - 256mm; 5- boulder, > 256mm; 6- bedrock; 7- manmade

Bank Erosion: 0- not evident; 1- light fluvial; 2- moderate fluvial; 3- heavy fluvial / mass wasting

64. Comments (bank material variation, minor inflows, protection extent, etc.):

4325

63. Some of the bed material under the bridge towards the left abutment is concrete. The bed is also tightly packed cobble and gravel with some sand and boulders.

The bridge deck was widened and two steel I beams were added to the US end. The US left wingwall extends underneath the bridge deck. 
65. Debris and Ice Is there debris accumulation?

(Yor $N)$ 66. Where? $\underline{Y}$

(1- Upstream; 2- At bridge; 3- Both)

67. Debris Potential 1 (1-Low; 2-Moderate; 3- High)

68. Capture Efficiency 2

(1-Low; 2- Moderate; 3- High)

69. Is there evidence of ice build-up? 2

Ice Blockage Potential $\underline{\mathbf{Y}}$

(1-Low; 2- Moderate; 3- High)

70. Debris and Ice Comments:

1

67. 68. There are many large trees along both banks. Between ANDO039 and ANDO038 some very large trees are down in the middle of the channel.

69. There are some small scars on the trees.

\begin{tabular}{|l|c|c|c|c|c|c|c|c|}
\hline Abutments & $\begin{array}{c}\text { 71. Attack } \\
\angle \mathrm{BF})\end{array}$ & $\begin{array}{c}\text { 72. Slope } \\
(\mathrm{Qmax})\end{array}$ & $\begin{array}{l}\text { 73. Toe } \\
\text { loc. (BF) }\end{array}$ & $\begin{array}{c}\text { 74. Scour } \\
\text { Condition }\end{array}$ & $\begin{array}{c}\text { 75. Scour } \\
\text { depth }\end{array}$ & $\begin{array}{c}\text { 76. Exposure } \\
\text { depth }\end{array}$ & 77. Material & 78. Length \\
\hline LABUT & & $\mathbf{2 5}$ & $\mathbf{9 0}$ & $\mathbf{2}$ & $\mathbf{0}$ & - & - & $\mathbf{9 0 . 0}$ \\
\hline RABUT & $\mathbf{1}$ & $\mathbf{0}$ & $\mathbf{9 0}$ & & & $\mathbf{2}$ & $\mathbf{2}$ & $\mathbf{2 7 . 5}$ \\
\hline
\end{tabular}

Pushed: $L B$ or RB

Toe Location (Loc.): 0- even, 1- set back, 2- protrudes

Scour cond.: 0- not evident; 1- evident (comment); 2- footing exposed; 3-undermined footing; 4- piling exposed; 5- settled; 6- failed

Materials: 1- Concrete; 2- Stone masonry or drywall; 3- steel or metal; 4- wood

79. Abutment comments (eg. undermined penetration, unusual scour processes, debris, etc.):

0

0.7

1

76. Only the US end of the right abutment footing is exposed. A point bar covers the footing from $5 \mathrm{ft}$. under the bridge to the DS bridge face.

80. Wingwalls:

Exist? Material? Scour Scour Exposure $\begin{aligned} & 81 . \\ & \text { Angle? Length? }\end{aligned}$ Condition? depth? depth?

USLWW:

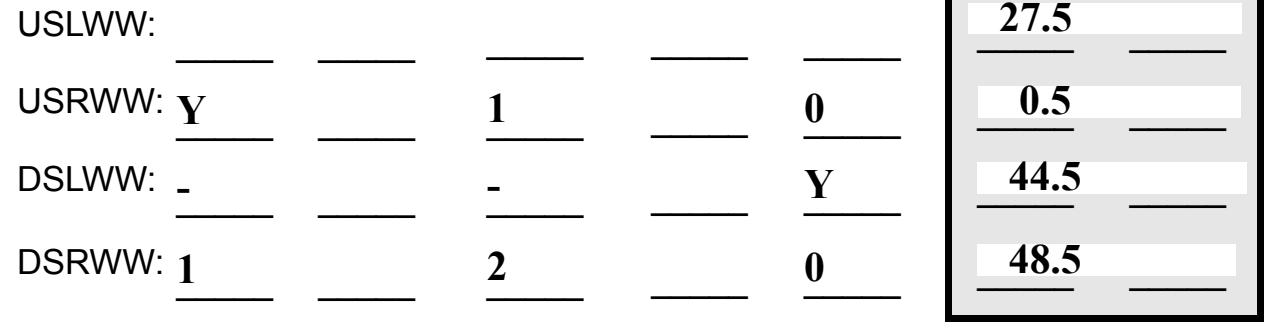

Wingwall materials: 1- Concrete; 2- Stone masonry or drywall; 3- steel or metal; 4- wood

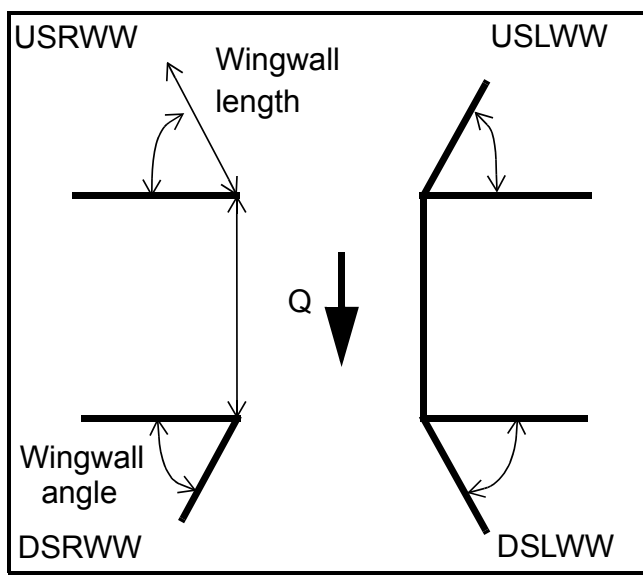

82. Bank / Bridge Protection:

\begin{tabular}{|l|l|l|l|l|l|l|l|c|}
\hline Location & USLWW & USRWW & LABUT & RABUT & LB & RB & DSLWW & DSRWW \\
\hline Type & $\mathbf{1 . 2}$ & $\mathbf{0}$ & $\mathbf{Y}$ & - & $\mathbf{1}$ & $\mathbf{2}$ & - & - \\
\hline Condition & $\mathbf{Y}$ & - & $\mathbf{1}$ & - & $\mathbf{1}$ & $\mathbf{2}$ & - & - \\
\hline Extent & $\mathbf{1}$ & - & $\mathbf{0}$ & $\mathbf{3}$ & $\mathbf{2}$ & $\mathbf{0}$ & $\mathbf{0}$ & - \\
\hline
\end{tabular}

Bank / Bridge protection types: 0- absent; 1-<12 inches; 2- < 36 inches; 3- < 48 inches; 4- < 60 inches; 
83. Wingwall and protection comments (eg. undermined penetration, unusual scour processes, etc.):

$-$

$-$

$-$

$-$

0

-

0

0

\section{Piers:}

84. Are there piers? $\mathbf{8 0 .}$ ( $Y$ or if $N$ type ctrl-n pr)

\begin{tabular}{|l|l|l|l|l|l|l|l|}
\hline \multirow{2}{*}{$\begin{array}{l}\text { Pier no. } \\
\text { Pien }\end{array}$} & \multicolumn{3}{|c|}{ width (w) feet } & \multicolumn{3}{c|}{ elevation (e) feet } \\
\cline { 2 - 8 } & w1 & w2 & w3 & e@w1 & e@w2 & e@w3 \\
\hline Pier 1 & & & & $\mathbf{1 2 0 . 0}$ & $\mathbf{1 1 . 5}$ & $\mathbf{1 5 . 0}$ \\
\hline Pier 2 & & & & $\mathbf{2 7 . 0}$ & $\mathbf{1 5 . 0}$ & $\mathbf{3 1 . 0}$ \\
\hline Pier 3 & & & - & $\mathbf{1 3 5 . 0}$ & $\mathbf{1 3 . 0}$ & - \\
\hline Pier 4 & - & - & - & - & - & - & w1 \\
\hline
\end{tabular}

\begin{tabular}{|l|l|l|l|l|}
\hline Level 1 Pier Descr. & \multicolumn{1}{|c|}{1} & \multicolumn{1}{|c|}{2} & 3 & 4 \\
\hline 86. Location (BF) & A piece & rest of & & - \\
\hline 87. Type & of & the & & - \\
\hline 88. Material & con- & DS & & - \\
\hline 89. Shape & crete & left & & - \\
\hline 90. Inclined? & has & wing & N & - \\
\hline 91. Attack $\angle$ (BF) & dis- & wall. & - & - \\
\hline 92. Pushed & asso- & & - & - \\
\hline 93. Length (feet) & - & - & - & - \\
\hline 94. \# of piles & ciate & & - & - \\
\hline 95. Cross-members & d & & - & - \\
\hline 96. Scour Condition & itself & & - & - \\
\hline 97. Scour depth & from & & - & - \\
\hline 98. Exposure depth & the & & - & - \\
\hline
\end{tabular}

LFP, LTB, LB, MCL, MCM, MCR, RB, RTB, RFP

1- Solid pier, 2-column, 3- bent

1-Wood; 2-concrete; 3- metal; 4- stone

1- Round; 2- Square; 3- Pointed

Y-yes; $N$ - no

$L B$ or $R B$

0- none; 1- laterals; 2- diagonals; 3- both

0- not evident; 1- evident (comment);

2- footing exposed; 3- piling exposed;

4- undermined footing; 5- settled; 6-failed 
99. Pier comments (eg. undermined penetration, protection and protection extent, unusual scour processes, etc.):

-
-
-
-
-
-
-
-
-
-

100.

\section{E. Downstream Channel Assessment}

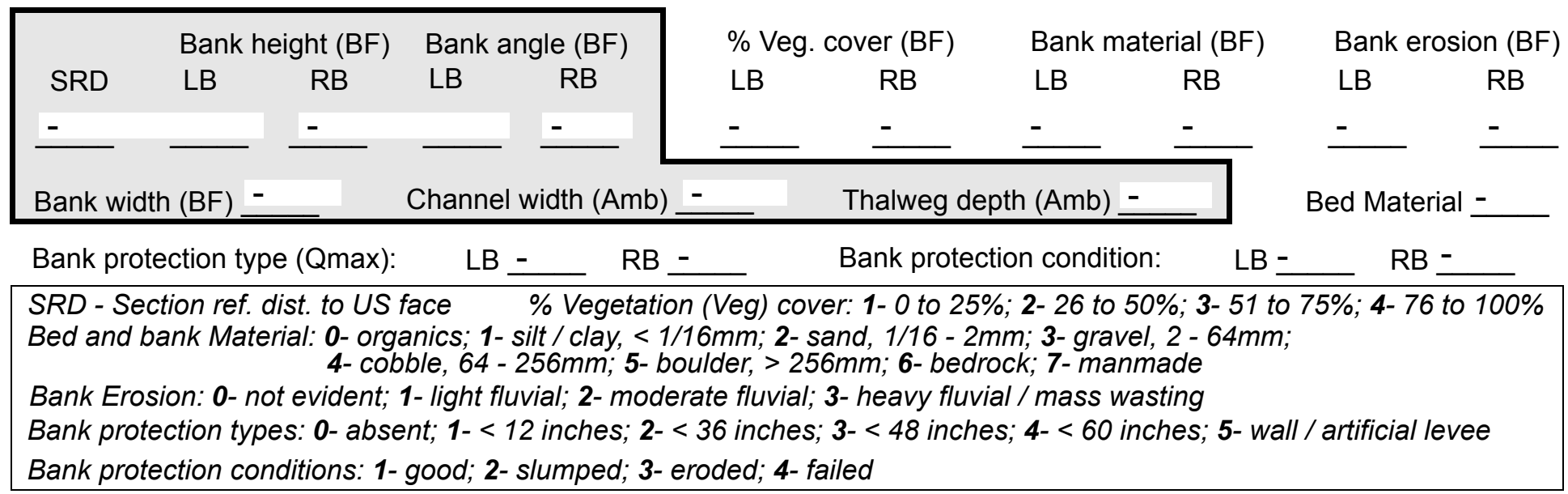

Comments (eg. bank material variation, minor inflows, protection extent, etc.):

$-$

$-$

$-$

$-$

$-$

$-$

$-$

$-$

NO PIERS

101. Is a drop structure present? ( $Y$ or $N$, if $N$ type ctrl-n $d s)$

102. Distance: - feet

103. Drop: - $\quad$ feet 104. Structure material: (1- steel sheet pile; 2- wood pile; 3- concrete; 4- other)

105. Drop structure comments (eg. downstream scour depth): 
106. Point/Side bar present? 2 (Y or N. if N type ctrl-n pb)Mid-bar distance:

Point bar extent: $\underline{\mathbf{0}}$ feet -

(US, UB, DS) to feet $\underline{\mathbf{T h}}$ (US, UB, DS) positioned $\underline{\mathbf{e}}$ $\%$ LB to be $\%$ RB

Material: d

Point or side bar comments (Circle Point or Side; note additional bars, material variation, status, etc.):

material also consists of broken off pieces of concrete.

Is a cut-bank present? (Y or if $N$ type ctrl- $n$ cb) Where? (LB or $R B)$

Mid-bank distance:

Cut bank extent: feet (US, UB, DS) to feet (US, UB, DS)

Bank damage: (1- eroded and/or creep; 2- slip failure; 3- block failure)

Cut bank comments (eg. additional cut banks, protection condition, etc.):

$\mathbf{N}$

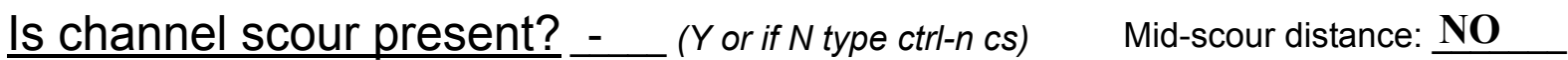

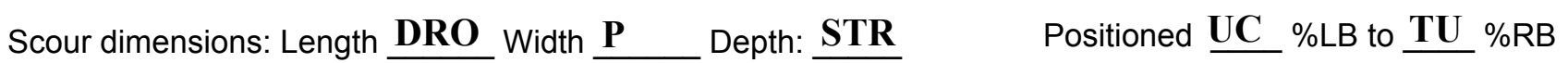
Scour comments (eg. additional scour areas, local scouring process, etc.):

RE

Are there major confluences? ( $Y$ or if $N$ type ctrl-n $m c)$

How many?

Confluence 1: Distance $\mathbf{Y}$ Enters on $\underline{\mathbf{2}}$ (LB or RB)

Type 17 (1-perennial; 2- ephemeral)

Confluence 2: Distance $\mathbf{5}$ Enters on $\underline{\mathbf{U B}}$ (LB or RB)

Type $\underline{48}$ (1- perennial; 2- ephemeral)

Confluence comments (eg. confluence name):

DS

50

\section{F. Geomorphic Channel Assessment}

107. Stage of reach evolution

1- Constructed

2- Stable

3- Aggraded

4- Degraded

5- Laterally unstable

6- Vertically and laterally unstable 
108. Evolution comments (Channel evolution not considering bridge effects; See HEC-20, Figure 1 for geomorphic descriptors):

325

Vegetation on the point bar is grass. An additional point bar extends from $20 \mathrm{ft}$. DS to $145 \mathrm{ft}$. DS. The mid-bar distance is $82 \mathrm{ft}$. and the width is $21 \mathrm{ft}$. It is positioned $0 \% \mathrm{LB}$ to $45 \% \mathrm{RB}$ and the material is gravel, sand, and boulders.

$\mathbf{Y}$

RB

82

46

DS

127

DS

1 


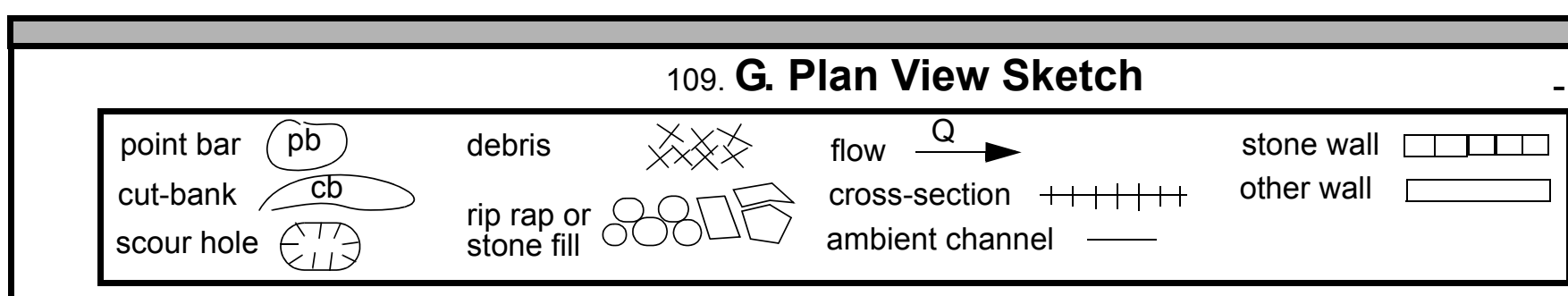


APPENDIX F:

SCOUR COMPUTATIONS 
SCOUR COMPUTATIONS

\begin{tabular}{|c|c|c|c|}
\hline Structure Number: ANDOVT00110039 & & Town: & ANDOVER \\
\hline Road Number: $\quad$ VT011 & & County: & WINDHAM \\
\hline MIDDLE BRANCH OF & THE WILLIA & AMS RIVER & \\
\hline Initials RLB & Checked: & SAO & \\
\hline Analysis of contraction scour, live & -bed or cl & Lear wate & \\
\hline $\begin{array}{l}\text { Critical Velocity of Bed Material } \\
\text { VC=11.21*y1^0.1667*D50^0.33 with Ss } \\
\text { (Richardson and others, 1995, p. } 28\end{array}$ & $\begin{array}{l}\text { (converted } \\
s=2.65 \\
3, \text { eq. } 16)\end{array}$ & to Engli & sh units \\
\hline pproach section & & & \\
\hline Characteristic & $100 \mathrm{yr}$ & $500 \mathrm{yr}$ & other $Q$ \\
\hline Total discharge, cfs & 1980 & 2900 & 2250 \\
\hline Main Channel Area, ft2 & 382 & 504 & 449 \\
\hline Left overbank area, ft2 & 8 & 50 & 30 \\
\hline Right overbank area, ft2 & 0 & 22 & 4 \\
\hline Top width main channel, ft & 51 & 51 & 51 \\
\hline Top width L overbank, ft & 16 & 19 & 18 \\
\hline Top width $\mathrm{R}$ overbank, ft & 0 & 38 & 7 \\
\hline D50 of channel, ft & 0.317 & 0.317 & 0.317 \\
\hline D50 left overbank, ft & -- & -- & -- \\
\hline D50 right overbank, ft & -- & -- & -- \\
\hline Y1, average depth, $M C$, ft & 7.5 & 9.9 & 8.8 \\
\hline Y1, average depth, LOB, ft & 0.5 & 2.6 & 1.7 \\
\hline Yl, average depth, ROB, ft & ERR & 0.6 & 0.6 \\
\hline Total conveyance, approach & 33630 & 55001 & 44496 \\
\hline Conveyance, main channel & 33558 & 53147 & 43802 \\
\hline Conveyance, LOB & 72 & 1344 & 608 \\
\hline Conveyance, ROB & 0 & 510 & 86 \\
\hline Percent discrepancy, conveyance & 0.0000 & 0.0000 & 0.0000 \\
\hline Qm, discharge, MC, cfs & 1975.8 & 2802.2 & 2214.9 \\
\hline Q1, discharge, LOB, cfs & 4.2 & 70.9 & 30.7 \\
\hline Qr, discharge, ROB, cfs & 0.0 & 26.9 & 4.3 \\
\hline $\mathrm{Vm}$, mean velocity $\mathrm{MC}$, ft/s & 5.2 & 5.6 & 4.9 \\
\hline Vl, mean velocity, LOB, ft/s & 0.5 & 1.4 & 1.0 \\
\hline Vr, mean velocity, ROB, ft/s & ERR & 1.2 & 1.1 \\
\hline Vc-m, crit. velocity, MC, ft/s & 10.7 & 11.2 & 11.0 \\
\hline Vc-l, crit. velocity, LOB, ft/s & ERR & ERR & ERR \\
\hline Vc-r, crit. velocity, ROB, ft/s & ERR & ERR & ERR \\
\hline Results & & & \\
\hline Live-bed(1) or Clear-Water(0) Contr & raction $\mathrm{Sco}$ & our? & \\
\hline Main Channel & 0 & 0 & 0 \\
\hline Left Overbank & $\mathrm{N} / \mathrm{A}$ & $\mathrm{N} / \mathrm{A}$ & $\mathrm{N} / \mathrm{A}$ \\
\hline Right Overbank & $\mathrm{N} / \mathrm{A}$ & $\mathrm{N} / \mathrm{A}$ & $\mathrm{N} / \mathrm{A}$ \\
\hline
\end{tabular}


Clear Water Contraction Scour in MAIN CHANNEL

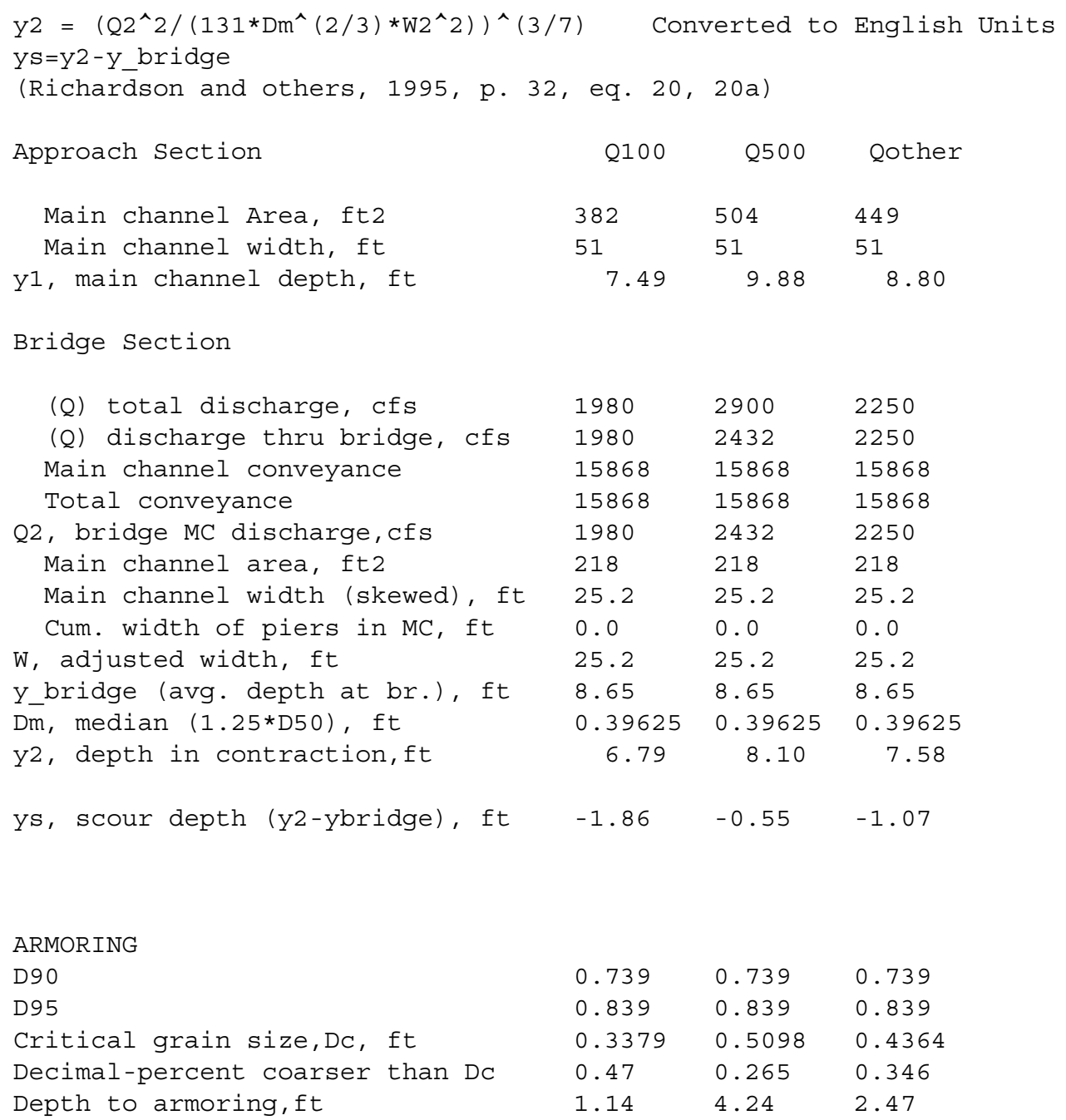




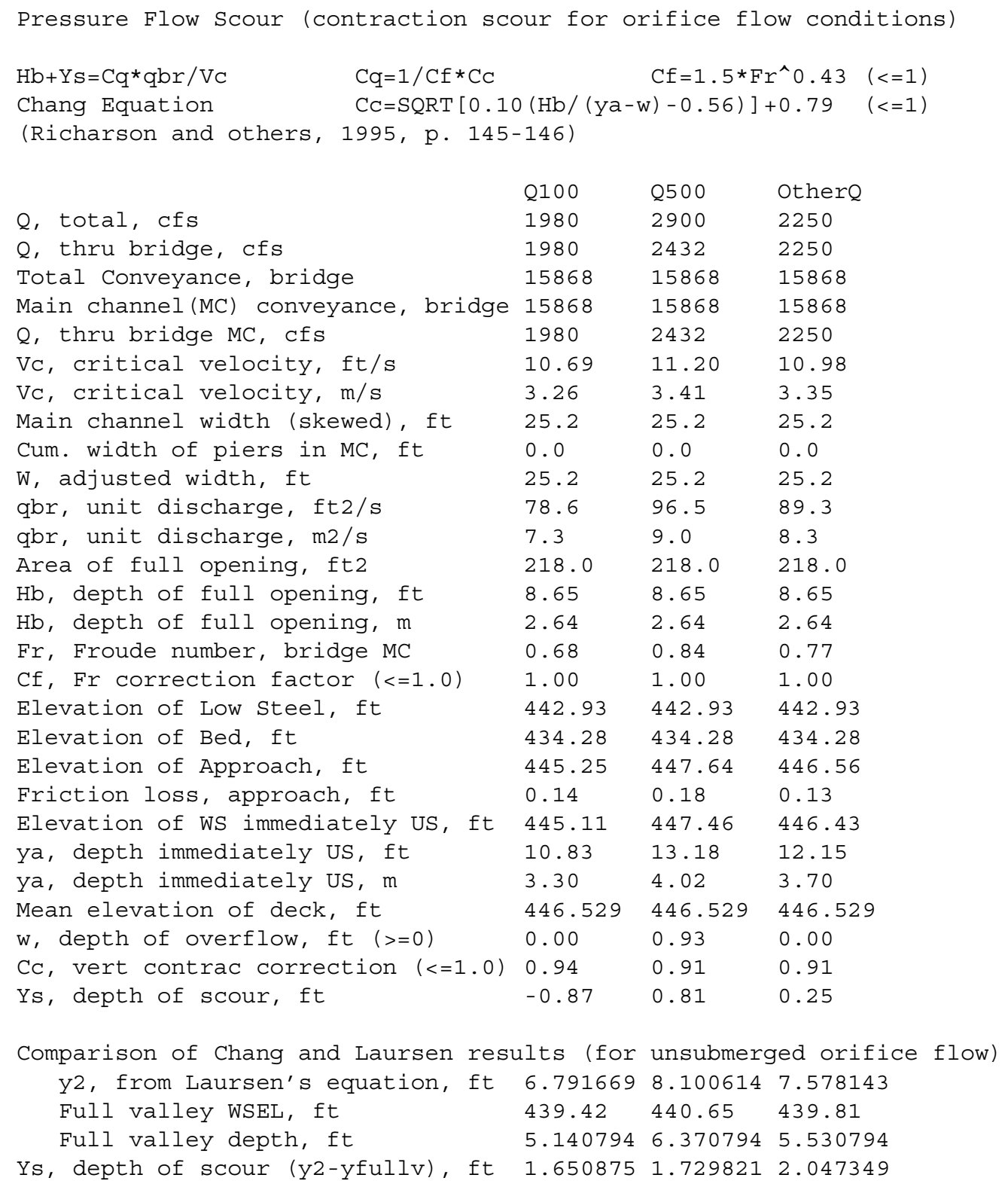




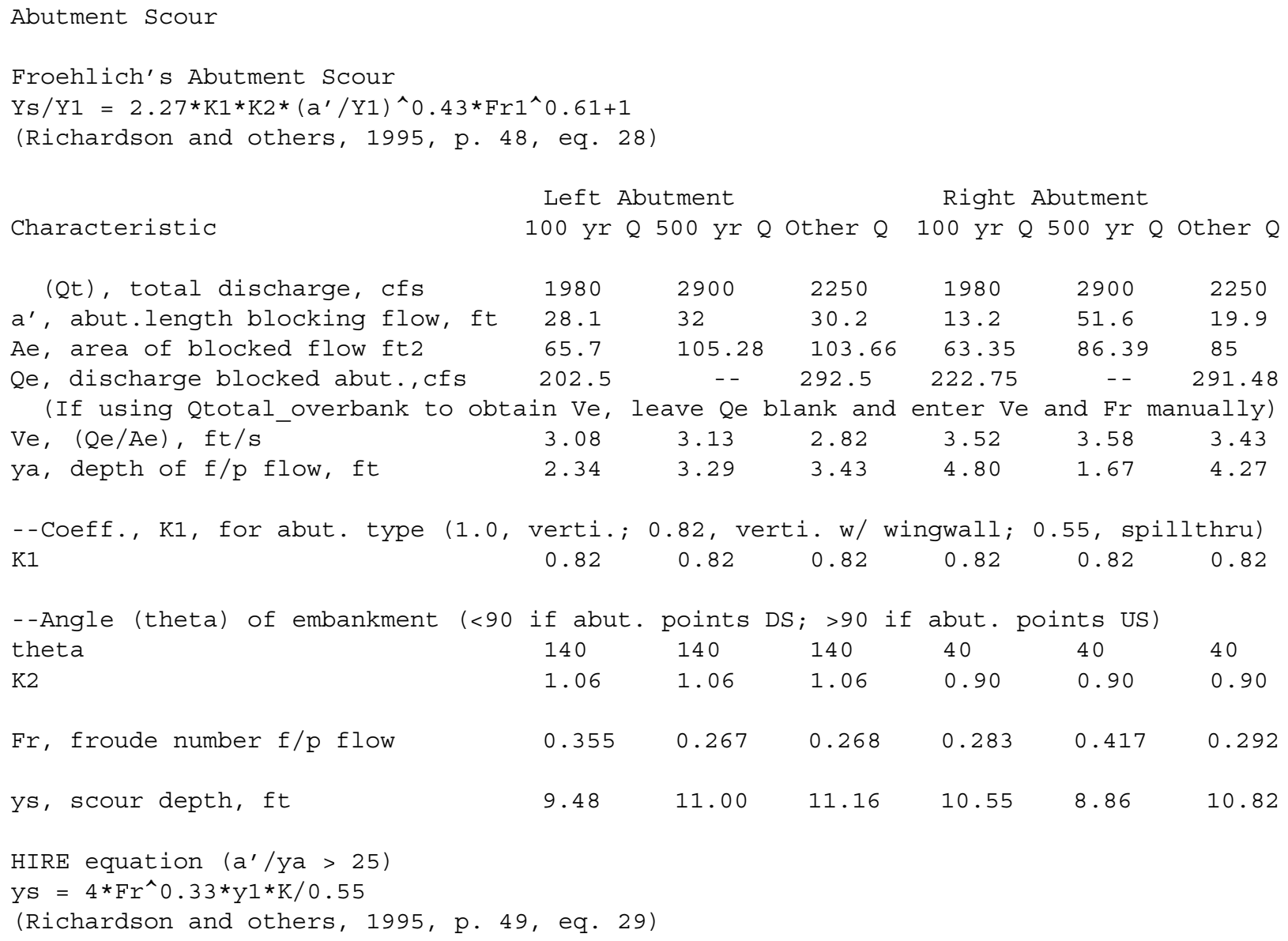




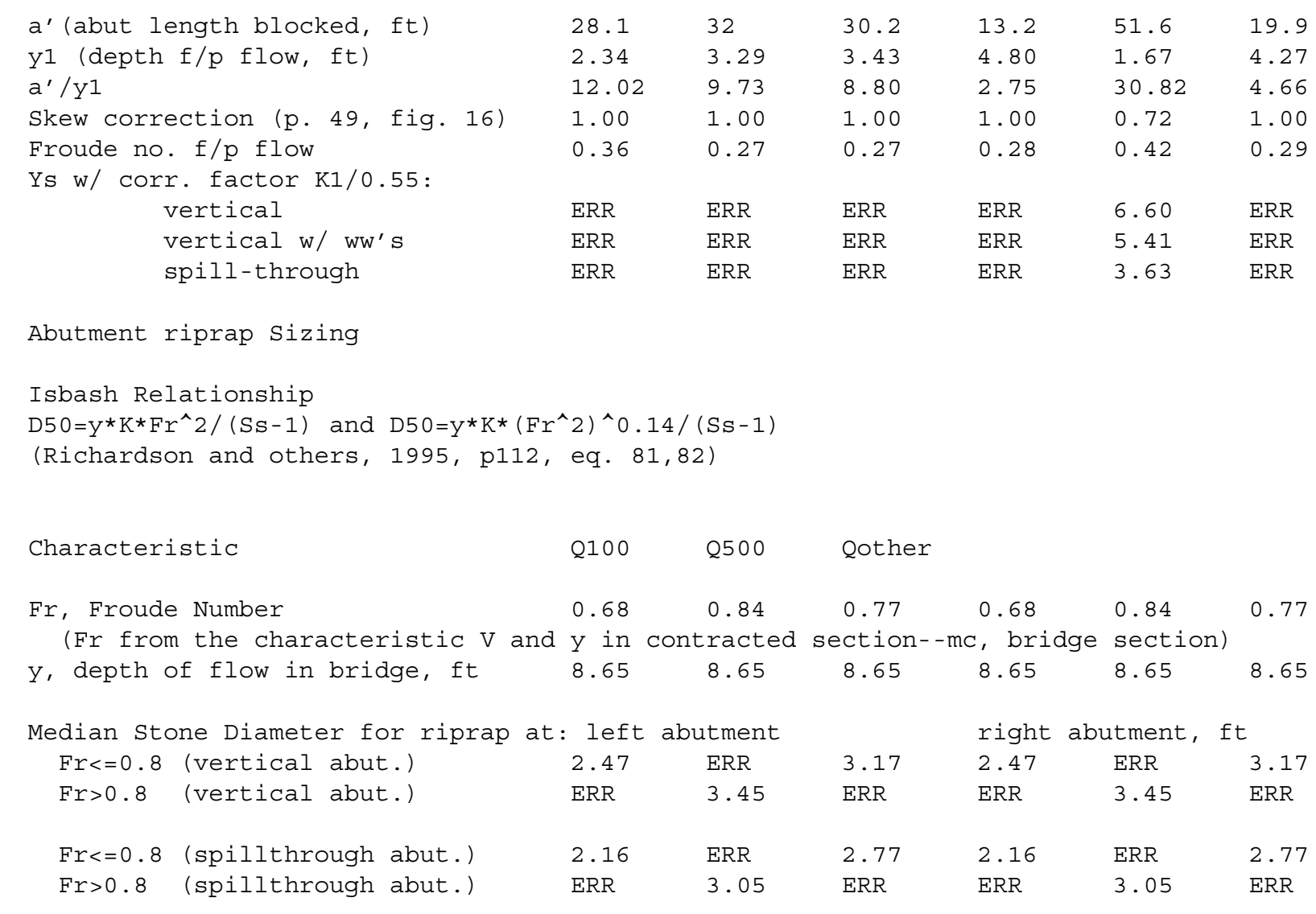


